\title{
Influence of conjugated linoleic acid and vitamin E on performance, energy metabolism, and change of fat depot mass in transitional dairy cows
}

\author{
S. Schäfers, ${ }^{*}$ D. von Soosten, ${ }^{* 1}$ U. Meyer, ${ }^{*}$ C. Drong, ${ }^{*}$ J. Frahm, ${ }^{*}$ J. Kluess, ${ }^{*}$ C. Raschka, $\dagger$ J. Rehage,† \\ A. Tröscher, $¥$ W. Pelletier,ł and S. Dänicke* \\ *Institute of Animal Nutrition, Friedrich-Loeffler-Institute (FLI), Federal Research Institute for Animal Health, Bundesallee 50, 38116 Brunswick, \\ Germany \\ †Clinic for Cattle, University of Veterinary Medicine, Foundation, Bischofsholer Damm 15, 30173 Hannover, Germany \\ ‡BASF SE, Chemiestraße 22, 68623 Lampertheim, Germany
}

\section{ABSTRACT}

The objective of this experiment was to determine the effects of conjugated linoleic acid (CLA) and vitamin $\mathrm{E}$ as well as their interaction on performance variables and lipomobilization during late pregnancy and early lactation (wk 6 antepartum until wk 10 postpartum). For this purpose, 59 pluriparous German Holstein cows were assigned to 4 dietary groups in a $2 \times 2$ design with the factors CLA and vitamin E at 2 levels. For this trial, we selected cows with a high body condition score because they are more likely to mobilize fat and consequently are at a higher risk of developing ketosis. Furthermore, concentrate proportions were adjusted to provoke ketosis. Lactation performance variables were analyzed in 3 periods (d 42 antepartum until calving, 1 to $21 \mathrm{~d}$ in milk, 22 to $70 \mathrm{~d}$ in milk). Dry matter intake and net energy intake were reduced in animals receiving CLA. Milk fat content was reduced in the CLA group compared with the control group (4.83 vs. $5.46 \%$ in period $2 ; 3.36$ vs. $4.57 \%$ in period 3 ). In the vitamin $\mathrm{E}$ and the CLA + vitamin E groups, reduction of milk fat content was observed in period 3 (3.76 vs. $4.57 \%$ compared with the control group). Milk yield was not affected by treatment. $\beta$-Hydroxybutyrate concentrations and liver lipid contents were not influenced by CLA or vitamin E. Moreover, longitudinal changes of adipose tissue depot mass were not affected by dietary treatments. Results suggest that the effects CLA had on milk composition were compensated by an increased milk yield and a decreased dry matter intake. Reduced milk energy output in CLA-treated animals was compensated by a reduced dry matter intake. Therefore, the net energy balance was not affected by either treat-

Received August 18, 2016.

Accepted December 10, 2016.

${ }^{1}$ Corresponding author: dirk.von_soosten@fli.de ment. Consequently, we found no group effect on the mobilization of adipose tissue.

Key words: dairy cow, conjugated linoleic acid, vitamin E, fat depot

\section{INTRODUCTION}

During the transition period, dairy cows are confronted with profound changes in their metabolic status. The increased nutrient demand caused by the growth of the fetus and the onset of lactogenesis cannot be compensated due to a reduced feed intake (Grummer et al., 1995). This results in a negative energy balance, which is partly compensated by the mobilization of fatty acids from adipose tissue and $\beta$-oxidation with the help of oxaloacetate in the liver. In a state of energy deficit, oxaloacetate is mainly needed for gluconeogenesis; therefore, a relative lack of oxaloacetate exists in the citrate cycle. As a consequence, the fatty acids can only partly be metabolized by the liver and ketone bodies (acetate, acetoacetate, and BHB) are produced from acetyl-CoA. Although ketone bodies can serve as an energy source for skeletal muscle, heart, kidney, and mammary glands in ruminants, Heitmann et al. (1987) showed that the extraction percentages of ketone bodies from blood by these organs are constant. Consequently, a higher ketone body production in the liver results in higher blood levels. Levels of BHB higher than $1.2 \mathrm{mmol} / \mathrm{L}$ are defined as the threshold for subclinical ketosis (Nielen et al., 1994). According to Schulz et al. (2014), a high concentrate proportion before calving, a high BCS at calving, and a delayed increase of concentrate proportion after parturition stimulate lipolysis; as a consequence, cows are more sensitive to develop a subclinical ketosis. Subclinical ketotic cows show no clinical signs of ketosis, but their reproductive health and economic productivity might be impaired (Drackley, 1999; Janovick et al., 2011). Therefore, the main objective of feeding in the transitional phase is the reduction of 
the negative energy balance. As milk fat is the major source of energy in milk, a reduction of milk fat percentage leads to a reduced milk energy output and, consequently, might partly counterbalance the negative energy balance. Baumgard et al. (2000) showed that the trans-10,cis-12 isomer of CLA is specifically responsible for the reduction of milk fat content and total milk fat yield (milk fat depression) by reducing the de novo milk fat synthesis in the udder, which results in a more efficient use of the ME. However, according to Bauman et al. (2008), supplementation of CLA in the state of early lactation or underfeeding also leads to a higher total milk yield and, therefore, repartitioning of energy. Consequently, CLA might have no significant effect on the total energy balance of the animal. Energy-dense diets antepartum (a.p.) lead to an increased DMI and increased accretion of internal fat depots without influencing carcass weight or BCS (Drackley et al., 2014). Pronounced lipomobilization caused by high fat depot mass is a risk factor for fatty liver and ketosis (Grummer, 1993; Bobe et al., 2004) and enhances the sensitivity to oxidative stress (Bernabucci et al., 2005), whereas vitamin $\mathrm{E}$ acts as an antioxidant (Rimbach et al., 2002; Nakamura and Omaye, 2010). Conjugated linoleic acid has been shown to have a decelerating influence on the mobilization of the retroperitoneal adipose tissue depot (von Soosten et al., 2011). To the contrary, Akter et al. (2011) reported a lipolytic or antilipogenic effect of CLA on the adipose tissue. This makes it necessary to evaluate the influence of CLA on lipomobilization. Literature indicates possible interactions between CLA and vitamin E, as CLA enhances $\alpha$-tocopherol concentration in muscle tissue (Schlegel et al., 2012), probably by preventing the degradation of vitamin $\mathrm{E}$ in the liver (Chao et al., 2010). Furthermore, Pottier et al. (2006) observed an influence of vitamin $\mathrm{E}$ on biohydrogenation pathways in the rumen, where vitamin E counteracted the trans-11 to trans-10 shift.

Therefore, the current experiment aimed to investigate the effect that CLA has on lactation performance, energy metabolism, and lipomobilization, as well as the interactions between CLA and vitamin E in dairy cows during the transition period and the first 10 wk of lactation. Our objective was to clarify the influence that CLA has on lipomobilization of fat depots and resulting subclinical ketosis. Furthermore, we wanted to evaluate whether treatment with vitamin $\mathrm{E}$ reduces the milk fat-decreasing effect of CLA.

\section{MATERIALS AND METHODS}

The study was conducted at the experimental station of the Friedrich Loeffler Institute in Brunswick, Ger- many. The experiment was carried out in accordance with the German Animal Welfare Act approved by the LAVES (Lower Saxony State Office for Consumer Protection and Food Safety, Germany).

\section{Experimental Design and Diets}

The experimental design was a $2 \times 2$ factorial design with CLA and vitamin $\mathrm{E}$ as main factors, resulting in 3 intervention groups (CLA, vitamin $\mathrm{E}$, CLA + vitamin E) and 1 control group. We used the experimental strategies as proposed by Schulz et al. (2014) to generate cow groups suited for testing of possible protective effects of CLA and vitamin E. Sixty-four pluriparous German Holstein cows were allocated to these groups 8 wk prior $(-42 \mathrm{~d}$ a.p. $)$ to the calculated calving date based on their BCS (Edmonson et al., 1989), which was targeted higher than 3.5 with a standard deviation of 0.5 in each group. Further criteria were milk yield and milk composition of the previous lactation, BW, and number of lactation. In the control group, cows were in the second $(n=10)$, third $(n=4)$, fourth $(n=1)$, and fifth $(\mathrm{n}=1)$ lactation. For the CLA group, cows in the second $(\mathrm{n}=9)$, third lactation $(\mathrm{n}=3)$, fourth $(\mathrm{n}=1)$, sixth $(\mathrm{n}=1)$, eighth $(\mathrm{n}=1)$ and ninth $(\mathrm{n}=$ 1) lactation were included. In the vitamin E group, 10 cows were in their second $(\mathrm{n}=10)$, third $(\mathrm{n}=3)$, and fourth $(\mathrm{n}=2)$ lactation. Cows in the CLA + vitamin E group were in their second $(\mathrm{n}=5)$, third $(\mathrm{n}=4)$, fifth $(\mathrm{n}=1)$, and eighth $(\mathrm{n}=2)$ lactation. The study was divided into 3 periods: period 1 from $42 \mathrm{~d}$ a.p. until calving, period 2 from calving until d 21 postpartum (p.p.), and period 3 from d 21 until 70 p.p.

The animals were fed a standardized partial mixed ration (PMR) during the whole experiment, which was provided ad libitum by self-feeding stations (type RIC, Insentec B.V., Marknesse, the Netherlands). Concentrate was administered at $3 \mathrm{~kg} / \mathrm{d}$ per animal via computerized self-feeding stations (Insentec B.V.).

The components and the chemical composition of the feedstuffs are presented in Table 1. During the first period the ration was composed of $60 \%$ concentrate and $40 \%$ silage ( $50 \%$ maize, $50 \%$ grass silage on a DM basis). After parturition the concentrate proportion increased from 30 to $50 \%$ until d 21 p.p, where it remained until d 70 p.p. The treatment groups received either conjugated linoleic acid (BASF Lutrell, Lampertheim, Germany) containing $8.4 \mathrm{~g}$ of trans-10,cis-12 and $8.4 \mathrm{~g}$ of cis-9,trans-11 per day per animal (CLA, $\mathrm{n}=16$ ), 2,327 IU of vitamin E/d per animal (BASF Lutavit E 50; Vit. E, $\mathrm{n}=15$ ), or both supplements (CLA + Vit. E, $\mathrm{n}=12$ ) from d 42 a.p. to 70 p.p. The control group $(\mathrm{n}=16)$ as well as the Vit. E group received a 
rumen-protected control fat supplement (BASF Silafat) for caloric balance. Silafat consists of hydrogenated vegetable fat, $11 \%$ of which is C16:0 (palmitic acid), $89 \%$ is C18:0 (stearic acid). All diets were isocaloric.

\section{Sample Collection}

Samples of roughage feed were taken twice weekly and pooled to a collective sample for periods of $4 \mathrm{wk}$. Concentrate samples were taken once weekly for every group and also pooled to a collective sample for periods of $4 \mathrm{wk}$.

Dry matter intake was recorded daily for each individual cow by computerized feeding stations for PMR and concentrate. The BCS was assessed by the same person weekly on a 5-point scale according to Edmonson et al. (1989) during the whole experiment. Live weight was recorded weekly in period 1 . In period 2 and 3 , cows were weighed twice daily after each milking.

Milk yield was assessed twice daily during milking at 0530 and $1530 \mathrm{~h}$ via automatic milk counters (Lemmer Fullwood GmbH, Lohmar, Germany). Milk samples were taken twice weekly and stored at $4^{\circ} \mathrm{C}$ until further analysis.

Blood samples were taken after morning milking on d 42, 14, 7, and 3 a.p. and d 1, 3, 7, 10, 14, 21, 28, 36, 42,56 , and 70 p.p. from a jugular vein using serum and EDTA-plasma tubes. Serum and plasma samples were

Table 1. Ingredients and chemical composition of concentrate and roughage during the experimental period from d 42 antepartum until $\mathrm{d} 70$ postpartum $^{1}$

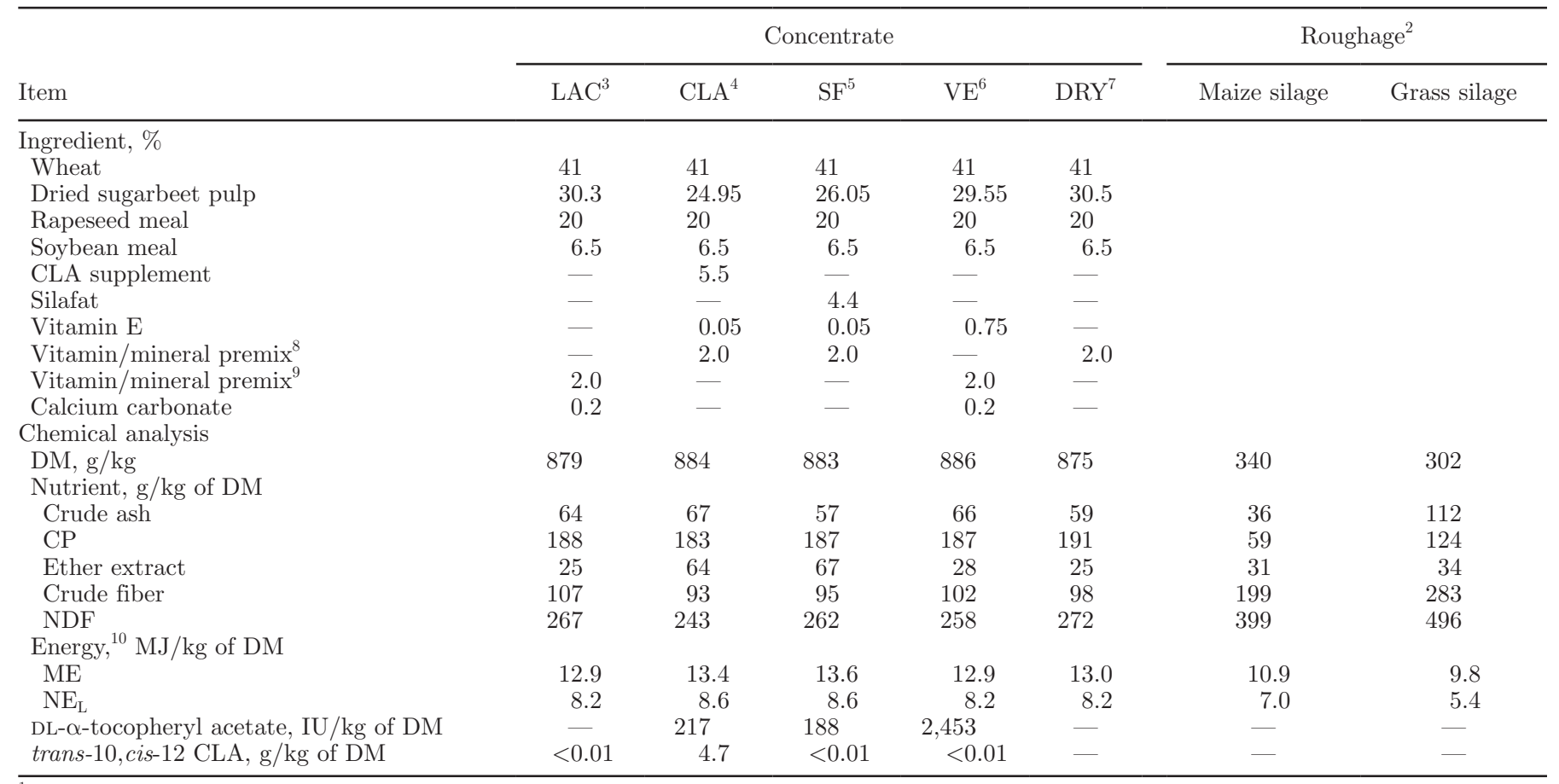

${ }^{1}$ Concentrate allocation (original substance) per group before parturition: control group: $2 \mathrm{~kg}$ of SF, $1 \mathrm{~kg}$ of LAC; CLA group: $2 \mathrm{~kg}$ of CLA, 1 $\mathrm{kg}$ of LAC; vitamin E group: $2 \mathrm{~kg}$ of SF, $1 \mathrm{~kg}$ of vitamin E; CLA + vitamin E group: $2 \mathrm{~kg}$ of CLA, $1 \mathrm{~kg}$ of vitamin E. Concentrate allocation (original substance) per group after parturition: control group: $2 \mathrm{~kg}$ of SF, $1 \mathrm{~kg}$ of LAC; CLA group: $2 \mathrm{~kg}$ of CLA, $1 \mathrm{~kg}$ of LAC; vitamin E group: $2 \mathrm{~kg}$ of SF, $1 \mathrm{~kg}$ of vitamin E; CLA + vitamin E group: $2 \mathrm{~kg}$ of CLA, $1 \mathrm{~kg}$ of vitamin E.

${ }^{2} 50 \%$ maize silage, $50 \%$ grass silage on a DM basis.

${ }^{3}$ Concentrate for lactation (LAC).

${ }^{4} \mathrm{CLA}$ concentrate.

${ }^{5}$ Silafat (SF) concentrate, BASF, Lampertheim, Germany.

${ }^{6}$ Vitamin E concentrate.

${ }^{7}$ Concentrate for dry cows.

${ }^{8}$ Ingredients per kilogram of mineral feed: $50 \mathrm{~g}$ of Ca; $120 \mathrm{~g}$ of Na; $70 \mathrm{~g}$ of P; $50 \mathrm{~g}$ of Mg; $7 \mathrm{~g}$ of Zn; $4.8 \mathrm{~g}$ of Mn; $1.3 \mathrm{~g}$ of $\mathrm{Cu} ; 100 \mathrm{mg}$ of I; $50 \mathrm{mg}$ of Se; $35 \mathrm{mg}$ of Co; 800,000 IU of vitamin A; 100,000 IU of vitamin $\mathrm{D}_{3}$.

${ }^{9}$ Ingredients per kilogram of mineral feed: $140 \mathrm{~g}$ of Ca; $120 \mathrm{~g}$ of Na; $70 \mathrm{~g}$ of P; $40 \mathrm{~g}$ of Mg; $6 \mathrm{~g}$ of Zn; $5.4 \mathrm{~g}$ of Mn; $1 \mathrm{~g}$ of Cu; $100 \mathrm{mg}$ of I; $40 \mathrm{mg}$ of Se; $25 \mathrm{mg}$ of Co; 1,000,000 IU of vitamin A; 100,000 IU of vitamin $\mathrm{D}_{3}$.

${ }^{10}$ Calculation based on equations for calculation of energy content in feedstuffs published by the GfE $(2001,2008,2009)$. 
centrifuged (Heraeus Varifuge 3.0R Heraeus, Osterode, Germany; $2,123 \times g, 15^{\circ} \mathrm{C}, 15 \mathrm{~min}$ ) and stored at $-80^{\circ} \mathrm{C}$ until analysis.

Liver biopsies of approximately $400 \mathrm{mg}$ /animal were taken from 31 cows at $\mathrm{d} 42$ a.p. and d 7, 28, and 70 p.p. Of the 31 cows, 8 were in the control, CLA and Vit. E groups, respectively. In the CLA + Vit. E group, biopsies were taken from 7 cows. All biopsies were collected under local anesthesia and sonographic control using the Bard Magnum biopsy system with corresponding sterile needles (C.R. Bard Inc., Murray Hill, NJ). Samples were immediately snap-frozen in liquid nitrogen and stored at $-80^{\circ} \mathrm{C}$ until analysis.

Ultrasonic measurements for the assessment of adipose tissues (subcutaneous, retroperitoneal, mesenteric, and omental) were performed at different sites on the animal according to Raschka et al. (2016). A Mindray M5 Vet (Mindray, Shenzhen, China) diagnostic ultrasound system equipped with a linear $(6 \mathrm{MHz}$, Mindray $6 \mathrm{LE} 5 \mathrm{Vs})$ and a convex probe (3 MHz, Mindray 3C5s) were used. To avoid bias, measurements were done without applying any external pressure and each site done in duplicate. The thickness of the fat layers was measured in millimeters and the following ultrasound sites were used in the subsequent calculation of adipose depots: on 12th rib at the same height as the last point (R12), at the point of interception of the line from the last lumbar vertebrae in the ventral direction and the line between the last rib and the greater trochanter parallel to the topline of the animal [skin to end of musculature (AW1b)], in the middle of the paralumbar fossa [skin to end of musculature (AW3b) and skin to peritioneum (AW3c)], backfat thickness (BFT), between the 2 next transverse processes cranial from the caudal pole of the kidney from dorsal between the transverse processes of the lumbar vertebrae measuring from skin to peritoneum [skin to peritoneum (KD2c)], and between the 2 next transverse processes cranial from KD2 [skin to end of kidney (KD3b)].

\section{Analyses}

Samples of PMR and concentrate were analyzed according to the standard methods defined by the VDLUFA (1993; method numbers in brackets) for DM (3.1), crude ash (8.1), CP (4.1.2), ether extract (5.1.1), crude fiber (6.1.1), as well as NDF. Concentrate samples were analyzed for tocopherol acetate according to a modified version of the tocopherol acetate JP ed16 method (JP Committee, Pharmaceutical Affairs and Food Sanitation Council, Japanese Minister of Health, Labour and Welfare, 2011). Conjugated linoleic acid isomers were analyzed by HPLC. Samples of maximal
$20 \mathrm{~g}$ were filled in Erlenmeyer flasks and mixed with 25 $\mathrm{mg}$ of butylhydroxytoluol, $300 \mathrm{mg}$ of sodium ascorbate, $45 \mathrm{~mL}$ of $\mathrm{H}_{2} \mathrm{O}, 40 \mathrm{~mL}$ of ethanol, and $10 \mathrm{~mL}$ of acetic acid. The expected CLA content was 6 to $300 \mathrm{mg}$. The Erlenmeyer flasks were placed in ultrasonic baths at $60^{\circ} \mathrm{C}$ for at least $15 \mathrm{~min}$. After cooling to room temperature $100 \mathrm{~mL}$ of cyclohexane/ethyl acetate (80:20) were added. The flasks were placed on a magnetic stirrer for $30 \mathrm{~min}$. After adding $70 \mathrm{~mL}$ of saturated saline solution, samples were stirred again for at least $10 \mathrm{~min}$. One milliliter of the extract was dried under nitrogen stream in a heating block at $60^{\circ} \mathrm{C}$. One milliliter of hydrogen chloride in methanol $(1.0 \mathrm{~mL}$ of acetyl chloride/100 $\mathrm{mL}$ of methanol) was added. After shaking for $20 \mathrm{~min}, 1 \mathrm{~mL}$ of $\mathrm{H}_{2} \mathrm{O}$ and $2 \mathrm{~mL}$ of cyclohexane were added and samples were shaken. The organic phase was filtered through a $0.45-\mu \mathrm{m}$ disposable filter into HPLC vials. The HPLC measurement was done using 3 ChromSpher 5 Lipids $(5 \mu \mathrm{m} ; 4.6 \times 250 \mathrm{~mm})$ columns (Varian, Agilent, Santa Clara, CA) and n-hexane/ acetonitrile/diethyl ether (994:1:5) as a mobile phase. Ten microliters of sample were injected at a flow rate of $1 \mathrm{~mL} / \mathrm{min}$. The oven temperature was kept at $10^{\circ} \mathrm{C}$. The wavelength of the detector was $233 \mathrm{~nm}$ with a bandwidth of $8 \mathrm{~nm}$. Gamma-tocopherol was analyzed with an in-house method. Milk samples were analyzed by an infrared milk analyzer (Milkoscan FT 6000; Foss Electric, Hillerød, Denmark) for fat, protein, lactose, and urea concentrations. Serum samples were analyzed for BHB, fatty acids, and glucose by a photometric measurement system (Eurolyser VET CCA, Salzburg, Austria). Samples of liver were analyzed for total lipid content using a gravimetrical method by Starke et al. (2010).

\section{Calculations and Statistical Analysis}

The performance variables DMI, energy intake, energy balance, milk yield, and milk components were calculated as weekly means before statistical evaluation. The variables of energy metabolism were calculated according to established equations. For calculating the $\mathrm{NE}_{\mathrm{M}}$ and $\mathrm{NE}_{\mathrm{L}}$ and the milk energy concentration, the equations published by the Society of Nutrition Physiology (GfE 2001) were used, where $\mathrm{BW}^{0.75}$ is metabolic BW:

$$
\mathrm{NE}_{\mathrm{M}}\left(\mathrm{MJ} \text { of } \mathrm{NE}_{\mathrm{L}} / \mathrm{d}\right)=0.294 \times \mathrm{BW}^{0.75}
$$

$\mathrm{NE}_{\mathrm{L}}\left(\mathrm{MJ}\right.$ of $\left.\mathrm{NE}_{\mathrm{L}} / \mathrm{d}\right)=$ [milk energy concentration

$\left(\mathrm{MJ}\right.$ of $\left.\left.\mathrm{NE}_{\mathrm{L}} / \mathrm{d}\right)+0.086\right] \times$ milk yield $(\mathrm{kg} / \mathrm{d})$, and 
Milk energy concentration $\left(\mathrm{MJ}\right.$ of $\left.\mathrm{NE}_{\mathrm{L}} / \mathrm{d}\right)=$

$0.3 \times$ milk fat $(\%)+0.21 \times$ milk protein $(\%)$

$$
+0.95 \mathrm{NE}_{\mathrm{L}}\left(\mathrm{MJ} \text { of } \mathrm{NE}_{\mathrm{L}} / \mathrm{d}\right) \text {. }
$$

The equation by Gaines (1928) was used to calculate the FCM:

$$
\begin{gathered}
4 \% \mathrm{FCM}(\mathrm{kg} / \mathrm{d})=\{[\text { milk fat }(\%) \times 0.15]+0.4\} \\
\times \text { milk yield }(\mathrm{kg} / \mathrm{d}) .
\end{gathered}
$$

For calculating the ECM, the equation by Sjaunja et al. (1990) was used:

$$
\begin{gathered}
\text { ECM }(\mathrm{kg} / \mathrm{d})=\text { milk yield }(\mathrm{kg} / \mathrm{d}) \times\{[38.3 \times \text { milk fat } \\
(\mathrm{g} / \mathrm{kg})+24.2 \times \text { milk protein }(\mathrm{g} / \mathrm{kg})+16.54 \\
\times \text { milk lactose }(\mathrm{g} / \mathrm{kg})+20.7] / 3,140\}
\end{gathered}
$$

The energy intake per day was calculated by multiplying the energy content of the feedstuff by the daily DMI. The following equation was used to calculate the net energy balance:

Net energy balance $\left(\mathbf{N E B} ; \mathrm{MJ}\right.$ of $\left.\mathrm{NE}_{\mathrm{L}} / \mathrm{d}\right)=$ energy intake (MJ of $\left.\mathrm{NE}_{\mathrm{L}} / \mathrm{d}\right)-\mathrm{NE}_{\mathrm{M}}\left(\mathrm{MJ}\right.$ of $\mathrm{NE}_{\mathrm{L}} / \mathrm{d}$ )

$$
-\mathrm{NE}_{\mathrm{L}}\left(\mathrm{MJ} \text { of } \mathrm{NE}_{\mathrm{L}} / \mathrm{d}\right) \text {, }
$$

Additionally, $13 \mathrm{MJ}$ of $\mathrm{NE}_{\mathrm{L}} / \mathrm{d}$ were subtracted from wk 6 to 3 a.p., and $18 \mathrm{MJ}$ of $\mathrm{NE}_{\mathrm{L}} / \mathrm{d}$ for the last 3 wk before calving to account for the additional late gestational requirements. The feed efficiency $(\mathrm{kg} / \mathrm{kg})$ was calculated by dividing ECM by DMI. To be able to compare the efficiency of the different feeding groups to the complete herd involved in this experiment, the residual energy intake (RSEI; Hurley et al., 2016) was calculated as a second variable of efficiency according to the following equation:

$\mathrm{RSEI}=\mathrm{NE}_{\mathrm{L}}$ measured intake $-\mathrm{NE}_{\mathrm{L}}$ estimated intake.

Variables and coefficients, which were used for calculating the estimated $\mathrm{NE}_{\mathrm{L}}$ intake, were evaluated using a nonlinear regression model.

The subcutaneous (SCAT), retroperitoneal (RPAT), omental (OMAT), and mesenteric (MAT) adipose tissue masses were calculated based on ultrasound measurements on different sites using the regressions according to (Raschka et al., 2016):

$$
\mathrm{SCAT}=-6.66+0.72 \times \mathrm{R} 12+0.31 \times \mathrm{AW} 3 \mathrm{c},
$$

$$
\begin{aligned}
\text { RPAT } & =-9.55+0.62 \times \mathrm{R} 12+0.06 \times \mathrm{KD} 3 \mathrm{~b}, \\
\mathrm{OMAT}= & -2.32+0.55 \times \mathrm{BFT}+0.37 \times \mathrm{AW} 3 \mathrm{~b}, \text { and } \\
\mathrm{MAT}= & -12.8+0.38 \times \mathrm{AW} 1 \mathrm{~b}+1.73 \times \mathrm{AW} 3 \mathrm{~b} \\
& -1.45 \times \mathrm{AW} 3 \mathrm{c}+0.07 \times \mathrm{KD} 2 \mathrm{c} .
\end{aligned}
$$

To evaluate accretion or mobilization of each adipose depot, the mean change between d 42 a.p. and 7 p.p. (phase 1), d 8 and 28 p.p. (phase 2), as well as between d 29 and 70 p.p. (phase 3) were calculated and divided by the number of days for the respective phase. To calculate the prevalence of subclinical $(1.2 \mathrm{mmol} / \mathrm{L}$ $<\mathrm{BHB}<3 \mathrm{mmol} / \mathrm{L}$ ) and clinical ketosis (BHB $>3$ $\mathrm{mmol} / \mathrm{L}$ ), each cow reaching the subsequent values during the trial was counted as one case.

The statistical analyses were performed using the SAS software package (version 9.4; SAS Institute Inc., Cary, NC). The procedure MIXED for repeated measures was used with a compound symmetry structure (Littell et al., 1998). The fixed effects in the model were CLA, vitamin E, and time and the interaction between them. Each cow within treatment was considered to be a random effect. The day or week of sampling was a repeated measure. For the blood variables and absolute fat depot masses, the value of the $\mathrm{d}-42$ sample was used as a covariate. $P$-values $>0.05$ and $\leq 0.10$ were considered to be a trend, whereas $P$-values $\leq 0.05$ were considered to be statistically significant after Tukey post-hoc test.

\section{RESULTS}

Fifty-nine out of the initial 64 cows completed the entire experiment. In the Vit. E group, 1 animal was excluded on d 4 p.p. because of multisystemic health problems. In the CLA + Vit. E group, 4 cows did not complete the trial due to 1 case of prolonged hypocalcemia, 2 cases of abomasal displacement, and 1 case of an impaired locomotion system. We did not observe any influences of treatment on health events.

Conjugated linoleic acid had a reducing influence on the DMI (Table 2; $P=0.022$ ); however, differences between groups were not significant and the same holds true for the net energy intake. Dry matter intake as well as net energy intake decreased from period 1 to 2 and increased from period 2 to 3 . Both changes were significant in all groups. Neither CLA nor Vit. E affected the calculated NEB (Table 2). We noted a trend for a treatment $\times$ period interaction $(P=0.054)$ driven by the Vit. E group, which tended to have a higher positive NEB in period 1 and a lower negative NEB in period 2 than the other groups. However, the dif- 
Table 2. Dry matter intake, net energy intake, net energy balance, BCS, and live weight (LSM) of the experimental groups during periods 1 (d 42 antepartum until calving), 2 (d 1 until 21 postpartum), and 3 (d 22 until 70 postpartum)

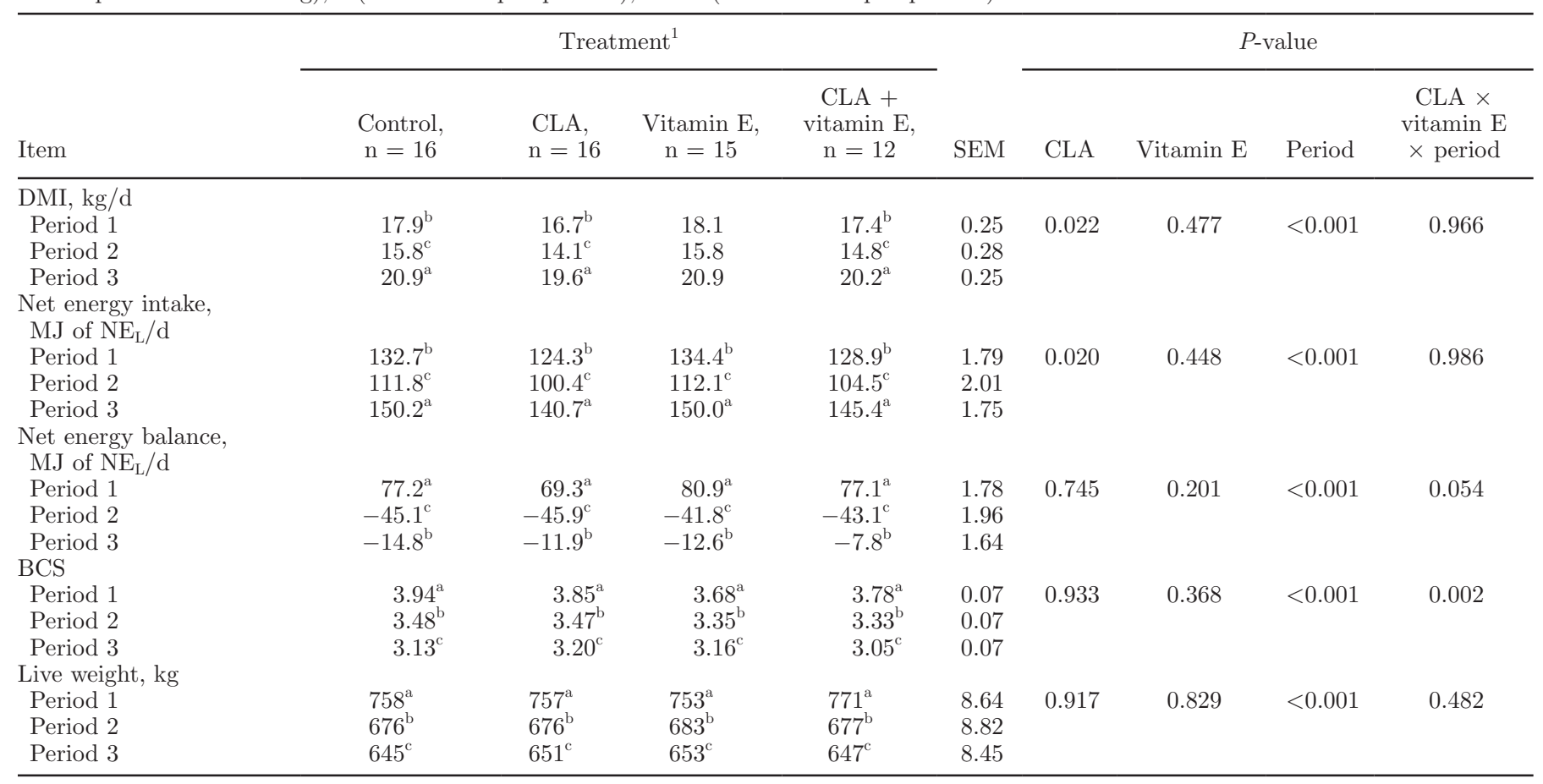

${ }^{a-c}$ Means with different superscripts within column differ $(P<0.05)$.

${ }^{1}$ Treatment: Before calving cows were fed a concentrate proportion of $60 \%$. Postpartum the concentrate proportion increased from 30 to $50 \%$ within 3 wk in all groups. CLA $(\mathrm{n}=16)$ and CLA + vitamin $\mathrm{E}(\mathrm{n}=12)$ received $8.4 \mathrm{~g}$ of trans-10, cis-12 CLA/d (BASF Lutrell, Lampertheim, Germany). Vitamin E $(\mathrm{n}=15)$ and CLA + vitamin E groups received 2,327 IU of vitamin E/d (BASF Lutavit E 50). The control group ( $\mathrm{n}=$ 16) as well as the vitamin E group received $88 \mathrm{~g} / \mathrm{d}$ of a rumen-protected fat supplement.

ferences between groups within each period were not significant. The BCS is presented in Table 2. Neither CLA nor Vit. E had an influence on the course of the $\mathrm{BCS}$; therefore, we did not find differences between the treatment groups. The BCS decreased from period 1 to 2 to 3 in all groups, which was also true for live weight (Table 2). The period influenced all described variables.

Variables of milk performance are presented in Table 3. We found no differences between treatments for milk yield, $4 \%$ FCM, ECM, feed efficiency (ECM/DMI and residual energy intake), protein content and yield, as well as lactose content and yield. An influence of CLA $(P<0.001)$ and a treatment $\times$ period interaction $(P<$ 0.001) were found for the milk fat content (Figure 1). Fat content was lower in the CLA group $(P=0.042)$ than in the control group during the second period. During the third period, milk fat content was lower in the CLA $(P<0.001)$ and the CLA + Vit. E group $(P<0.001)$ compared with the control group. Milk fat content was also reduced in the CLA $(P<0.001)$ and the CLA + Vit. E group $(P=0.041)$ compared with the Vit. E group. Milk fat yield (Figure 2) was not different between the groups in period 2. In period
3 , milk fat yield was lower in both groups receiving CLA compared with the control group. Neither milk protein content nor milk protein yield were different between treatments. The same is true for milk lactose content and milk lactose yield. We detected treatment $x$ period interaction for urea, as it was lower in the CLA group in comparison to the control $(P<0.001)$ and the Vit. E group $(P<0.001)$ during period 3 . We found a treatment $\times$ period interaction $(P<0.001)$ for the milk fat:protein ratio. This ratio was lower in the CLA group in period 2 compared with the control group $(P=0.048)$ and period 3 compared with the control group $(P<0.001)$ and the Vit. E group $(P<$ 0.001). Furthermore, we observed differences between the CLA + Vit. E and the control group $(P=0.006)$ in period 3. Conjugated linoleic acid had an influence on the milk energy output $(P=0.020)$. Whereas it tended to be higher in period 3 than in period 2 in all groups, we only found a difference between both periods in the control $(P=0.030)$ and the Vit. E group $(P=0.016)$; however, no differences were found between the 4 treatment groups within period. Period had an influence on all variables described except for $4 \%$ FCM. Variables 
Table 3. Lactation performance variables (LSM) of the experimental groups during period 2 (d 1 until d 21 postpartum) and period 3 (d 22 until d 70 postpartum)

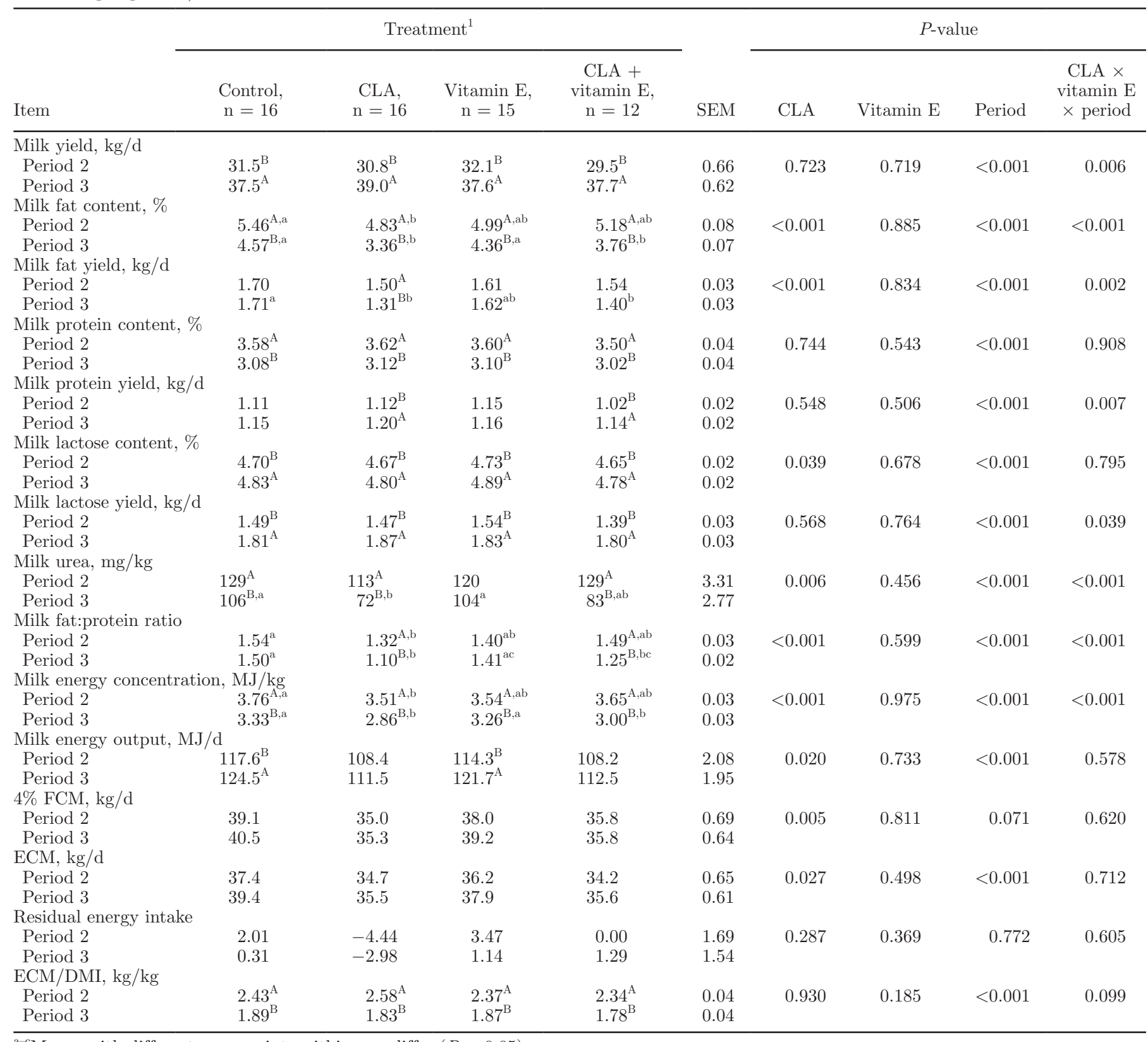

${ }^{\mathrm{a}-\mathrm{c}}$ Means with different superscripts within row differ $(P<0.05)$.

${ }^{\mathrm{A}, \mathrm{B}}$ Means with different superscripts within column differ $(P<0.05)$.

${ }^{1}$ Treatment: Before calving cows were fed a concentrate proportion of $60 \%$. Postpartum the concentrate proportion increased from 30 to $50 \%$ within 3 wk in all groups. CLA $(\mathrm{n}=16)$ and CLA + vitamin $\mathrm{E}(\mathrm{n}=12)$ received $8.4 \mathrm{~g}$ of trans-10, cis-12 CLA/d (BASF Lutrell, Lampertheim, Germany). Vitamin E $(\mathrm{n}=15)$ and CLA + vitamin E groups received 2,327 IU of vitamin $\mathrm{E} / \mathrm{d}$ (BASF Lutavit E 50). The control group ( $\mathrm{n}=$ 16) as well as the vitamin E group received $88 \mathrm{~g} / \mathrm{d}$ of a rumen-protected fat supplement.

and coefficients we used to calculate the RSEI were as follows:

$\mathrm{NE}_{\mathrm{L}}$ estimated intake $=16.458 \times$ lactation week

$-0.932 \times$ lactation week ${ }^{2}+1.447 \times \mathrm{ECM}$

$$
+0.211 \times \mathrm{BW}^{0.75} \text {. }
$$

We found no differences between groups or periods; neither CLA nor vitamin $\mathrm{E}$ had an influence on the RSEI (Table 3).

Absolute masses of fat depots per group are presented in Figure 3. Daily change of fat depots is presented in Table 4. We detected no influence of either CLA or 
vitamin $\mathrm{E}$ on subcutaneous and retroperitoneal adipose tissue. For the omental adipose tissue, on d 28 p.p. we found an influence of vitamin $\mathrm{E}(P=0.031)$ as well as an interaction between treatments $(P>0.001)$. The omental adipose tissue of the Vit. E group was higher compared with the control group $(P=0.046)$. For the omental adipose tissue, at d 70 p.p. we observed an interaction between treatments $(P=0.043)$; however, when comparing groups we found no differences. For mesenteric adipose tissue on d 28 p.p., we found an interaction between CLA and vitamin $\mathrm{E}(P=0.028)$. When comparing the groups, we detected that the Vit. E group has a higher mesenteric adipose tissue than the control $(P=0.017)$, CLA $(P=0.030)$, and the CLA + Vit. E group $(P=0.0215)$.

The subcutaneous tissue depots increased in all groups during phase 1 . During phases 2 and 3, it was mobilized; however, the mobilization in phase 3 was slower than in phase 2 . The daily change differed between phase 1 and phase 2 in all groups. We observed no differences between phase 1 and phase 3 as well as phase 2 and phase 3 within groups, except for the Vit. E group, in which the daily change in phase 3 differed from phase 1. Neither CLA nor vitamin E had an influence on the daily change. The retroperitoneal adipose tissue depot increased slightly during the first phase, whereas it was mobilized during the second and the third phase in all groups. In the control and the CLA groups, we found differences between phase 1 and phase 2 ; no influences of treatment were detected. We detected accretion of the mesenteric adipose tissue depot in phase 1 , whereas mobilization was found in phase 2 in all groups. We observed neither differences between groups nor influences of treatment. We found accretion of the omental adipose tissue depot in all groups during phase 1 . In phase 2 we detected mobilization, except for the Vit. E group, in which the depot further increased. During phase 3 we did not observe differences between groups. Changes of all described adipose tissue depots were influenced by phase $(P<0.001)$.

The serum concentrations of BHB during the trial are given in Figure 4. Concentrations of serum BHB, fatty acids, and glucose per period are given in Table 5. In the control group, the BHB values tended to be higher in period $2(P=0.066)$ and were higher in period $3(P$ $=0.002)$ than in period 1 . The BHB values in period 2 were enhanced compared with period 1 in CLA $(P=$ $0.050)$ and Vit. E group $(P=0.005)$. Values for BHB in the CLA + Vit. E group did not differ between periods; however, the values tended to be higher in period $2(P$

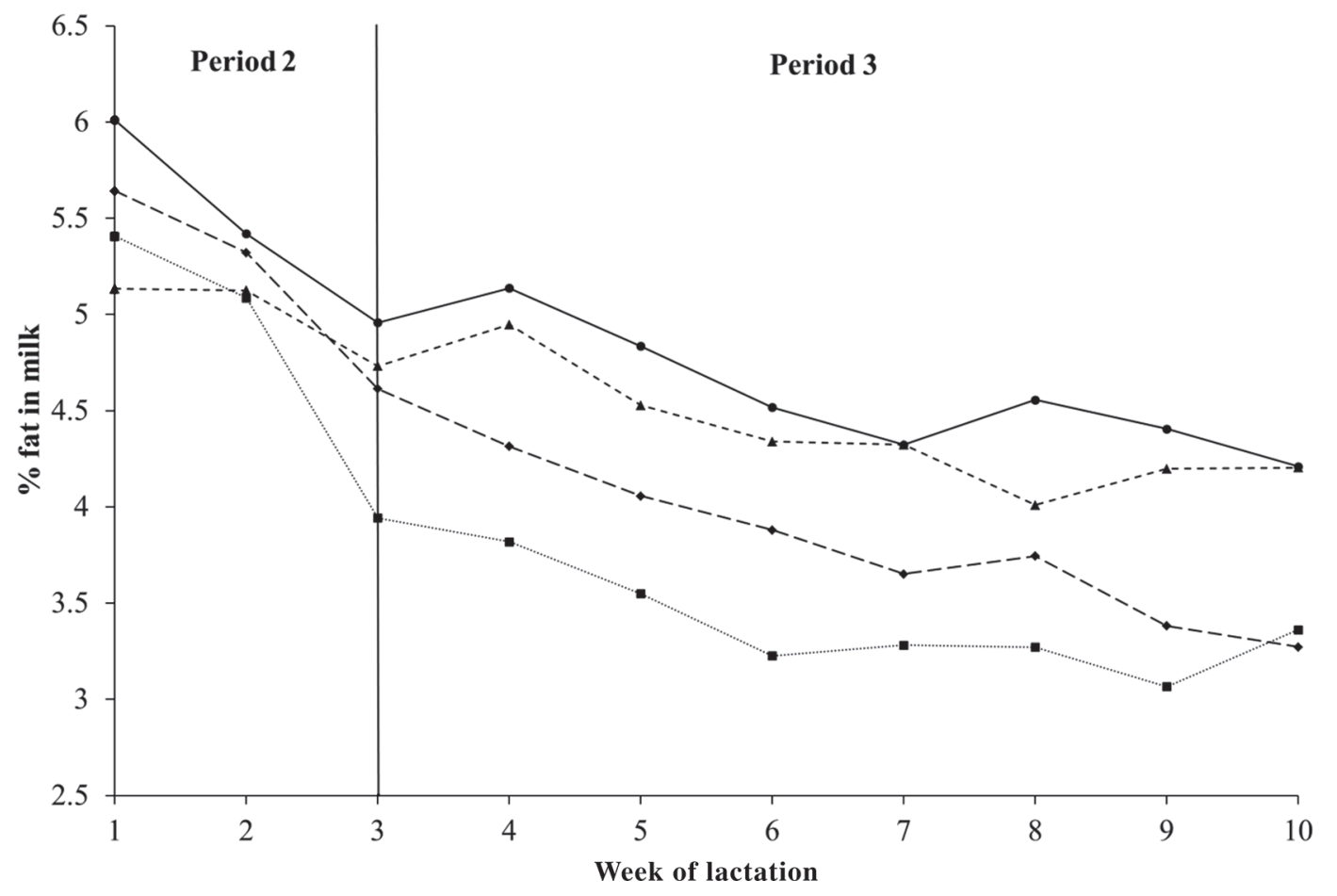

Figure 1. Milk fat percentage (LSM) during the experiment. Cows received a high-concentrate diet with a concentrate:roughage ratio of 60:40 antepartum. After parturition, concentrate:roughage ratio increased stepwise from 30:70 to 50:50 within $21 \mathrm{~d}$ in all groups. Groups included a control group $(\mathrm{n}=16)(\boldsymbol{\bullet}$, solid line), a CLA group receiving $8.4 \mathrm{~g}$ of trans-10, cis-12 CLA/d ( $=16$; $\mathbf{\square}$, dotted line), a vitamin $\mathrm{E}$ group $(\mathrm{n}=15)$ receiving $2,327 \mathrm{IU}$ of vitamin $\mathrm{E} / \mathrm{d}(\boldsymbol{\Lambda}$, short dashed line $)$, and a group $(\mathrm{n}=12)$ receiving both treatments $(\bullet$, long dashed line) from $\mathrm{d}-42$ until 70 relative to calving. 


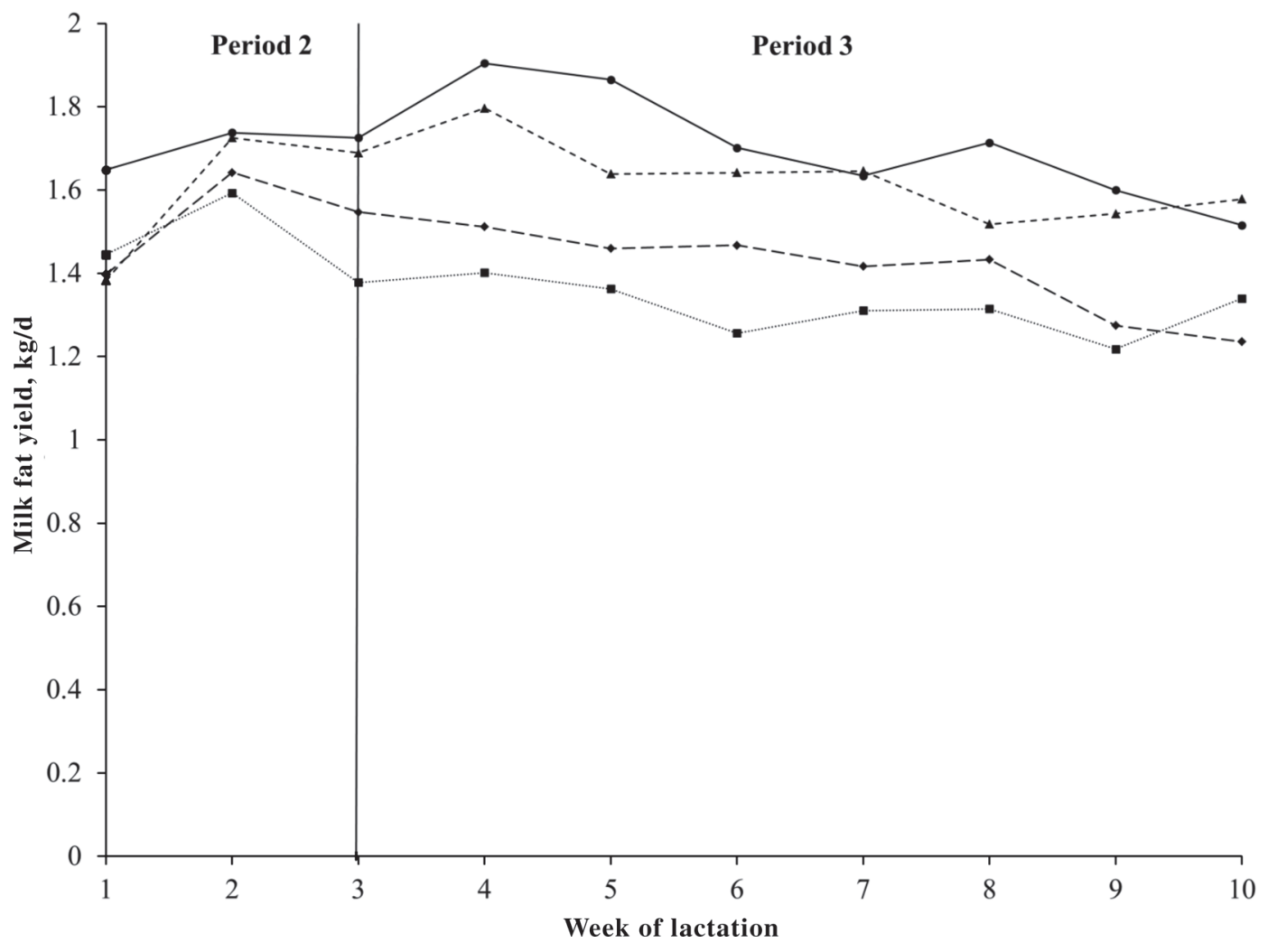

Figure 2. Milk fat yield (LSM) during the experiment. Cows received a high-concentrate diet with a concentrate:roughage ratio of $60: 40$ antepartum. After parturition concentrate:roughage ratio increased stepwise from 30:70 to 50:50 within $21 \mathrm{~d}$ in all groups. Groups included a control group $(\mathrm{n}=16)$ receiving $(\boldsymbol{\bullet}$, solid line), a CLA group receiving $8.4 \mathrm{~g}$ of trans-10, cis-12 CLA/d ( $\mathrm{n}=16 ; \boldsymbol{\square}$, dotted line), a vitamin $\mathrm{E}$ group $(\mathrm{n}=15)$ receiving $2,327 \mathrm{IU}$ of vitamin $\mathrm{E} / \mathrm{d}(\mathbf{\Lambda}$, short dashed line), and a group $(\mathrm{n}=12)$ receiving both treatments $(\bullet$, long dashed line) from $\mathrm{d}-42$ until 70 relative to calving.

$=0.053)$ than in period 1 . The prevalence of clinical ketosis (BHB $>3 \mathrm{mmol} / \mathrm{L}$ ) during the experiment was $25 \%$ in the control group, $27 \%$ in the CLA group, $13 \%$ in the Vit. E group, and $25 \%$ in the CLA + Vit. E group. Subclinical ketosis $(1.2 \mathrm{mmol} / \mathrm{L}<\mathrm{BHB}<3$ $\mathrm{mmol} / \mathrm{L}$ ) was detected in $63 \%$ of the control cows, $87 \%$ of the CLA group, $80 \%$ of the Vit. E group, and $67 \%$ of the CLA + Vit. E group. We did not find differences in prevalence of subclinical ketosis between groups. The fatty acid levels were higher in the second period compared with the other 2 periods for all groups. In the control group, a trend for higher fatty acid levels in period 3 than in period $1(P=0.073)$ was observed. Glucose values for the control group were reduced $(P$ $=0.003$ ) in period 2 compared with period 1 ; we detected no differences for period in the CLA group. In the Vit. E group, we found a reduction of glucose levels in period 2 compared with period $1(P=0.002)$ and compared with period $3(P=0.036)$. The same holds true for the CLA + Vit. E group, where we detected a $P$-value $<0.001$ for the comparison of period 1 and 2 and a $P$-value of 0.004 for the comparison between pe- riod 2 and 3. Neither CLA nor Vit. E had an influence on the BHB, fatty acids, and glucose. The period had a significant influence on all described blood variables.

The results of the total lipid analysis in liver tissue are presented in Table 6. Day of biopsy did elicit an influence $(P<0.001)$; however, only in the CLA group were differences between days of biopsy observed. Lipid levels were higher for biopsy on d $7(P=0.030)$ and 28 $(P=0.003)$ compared with $\mathrm{d}-42$.

\section{DISCUSSION}

The aim of the current experiment was the evaluation of the possible interaction between CLA and vitamin $\mathrm{E}$ and the subsequent effects on ketosis, lipomobilization, and lactation performance variables. It is known from the literature that cows at high body condition before calving are at special risk for postpartum excessive lipomobilization and ketosis (Gillund et al., 2001). Such a metabolic situation was shown to be suited to investigate the efficacy of intervention measures, such as Monensin-release boli (Kexxtone; Elanco, Bad Hom- 
burg, Germany) and dietary essential oils (Drong et al., 2016). Thus, to test the possible protective effects of CLA and vitamin E, we used the experimental strategies as proposed by Schulz et al. (2014) to generate suitable cow groups. In this model the combination of a high BCS before calving, a high concentrate proportion during the dry period, and a decelerated increase of the concentrate proportion p.p is responsible for a type II ketogenic metabolic status (Holtenius and Holtenius, 1996). This type of ketosis is characterized by a parallel increase of fatty acids and BHB very early in lactation and remarkable stress for the liver, whereas type 1 comes with a delayed BHB increase at approximately wk 4 of lactation and, typically, cows will not show symptoms of liver stress. The initial BCS at d 42 a.p. was above 3.5 in all 4 groups and increased further until calving, at which time it was at 4 on a 5 -point scale. Therefore, it is concluded that the requirements to induce a ketogenic metabolic status in the animals were achieved. This is emphasized by the high incidence of subclinical ketosis in all groups.

The DMI in animals receiving CLA was lower during all periods. Effects of CLA on DMI in literature are controversial. Pappritz et al. (2011) found a decrease of DMI during early lactation starting CLA supplementation $1 \mathrm{~d}$ after calving and continuing until wk 26 p.p. To the contrary, a DMI increase has been observed in several studies. The differences in result might also be attributed to a different CLA dose. Pappritz et al. (2011) administered a dose of $9 \mathrm{~g} / \mathrm{d}$ trans-10,cis-12 CLA, whereas Odens et al. (2007) provided the animals with $3.25 \mathrm{~g}$ of trans-10, cis-12 CLA daily. Metzger-Petersen (2012) found that $3.29 \mathrm{~g} / \mathrm{d}$ trans-10, cis-12 CLA given after parturition for $80 \mathrm{~d}$ into lactation increased DMI, whereas $3.22 \mathrm{~g}$ given daily for $120 \mathrm{~d}$ p.p. decreased DMI. Castañeda-Gutiérrez et al. (2005) reported a DMI increase at a daily dose of $9 \mathrm{~g}$ of trans-10, cis-12 CLA and a decrease at $18 \mathrm{~g}$ of trans-10,cis-12 CLA;
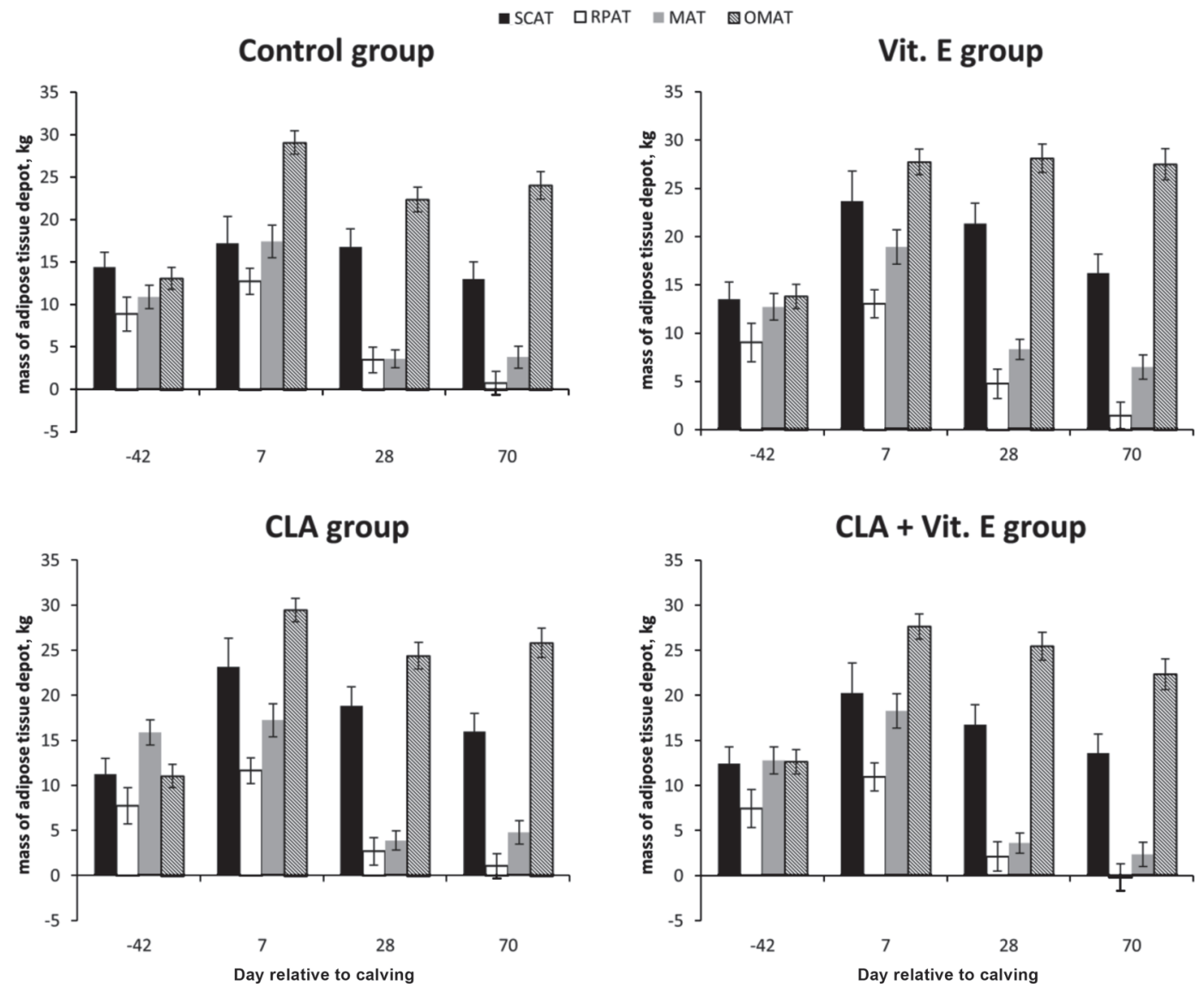

Figure 3. Absolute masses of adipose tissue depots (LSM) during the experiment. Cows received a high-concentrate diet with a concentrate:roughage ratio of 60:40 antepartum. After parturition concentrate:roughage ratio increased stepwise from 30:70 to 50:50 within 21 $\mathrm{d}$ in all groups. Groups included a control group $(\mathrm{n}=16)$, a CLA group receiving $8.4 \mathrm{~g}$ of trans-10,cis-12 CLA/d ( $\mathrm{n}=16)$, a vitamin E group $(\mathrm{n}=15)$ receiving $2,327 \mathrm{IU}$ of vitamin $\mathrm{E} / \mathrm{d}$, and a group $(\mathrm{n}=12)$ receiving both treatments from $\mathrm{d}-42$ until $\mathrm{d} 70$ relative to calving. SCAT, RPAT, MAT, and OMAT = subcutaneous, retroperitoneal, mesenteral, and omental adipose tissue, respectively. Error bars indicate SEM. 
Table 4. Change in adipose tissue depot mass (kg/d; LSM) of the experimental groups from d 42 antepartum (a.p.) until d 70 postpartum (p.p.)

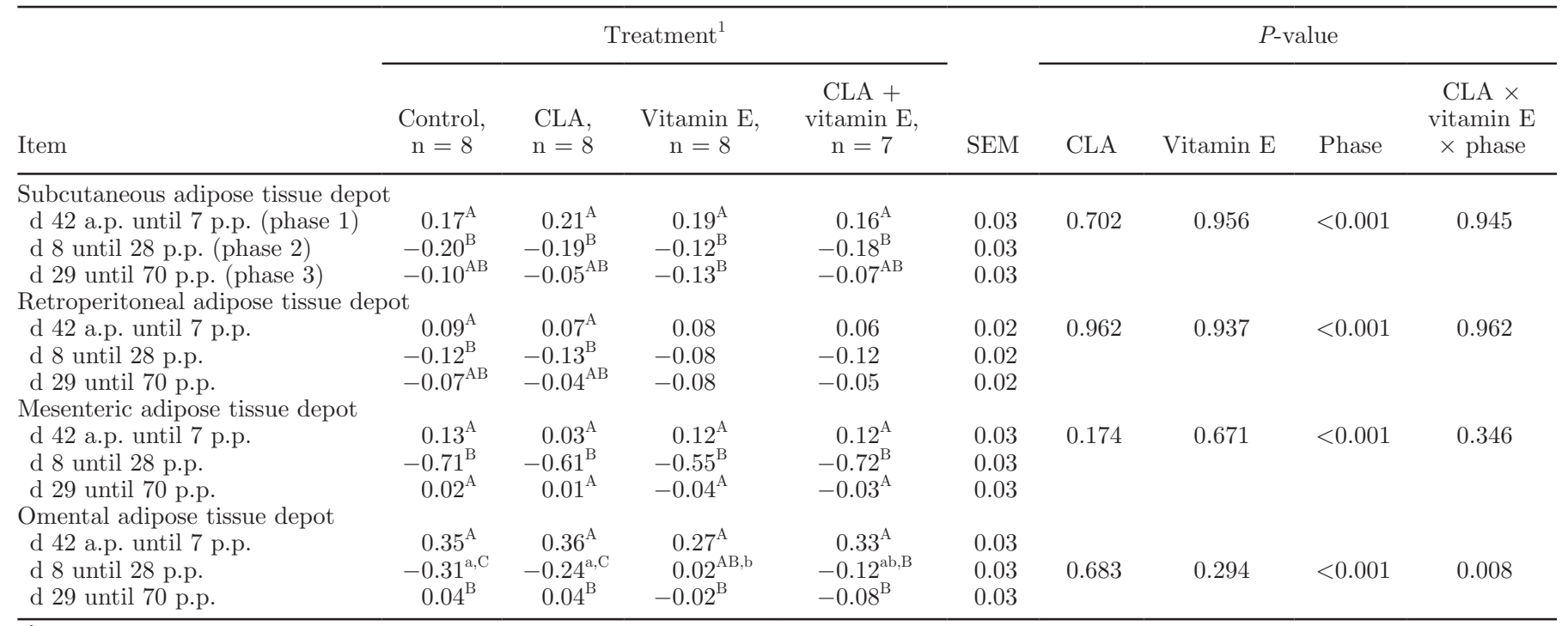

${ }_{\mathrm{a}, \mathrm{b}}$ Means with different superscripts within row differ $(P<0.05)$.

${ }^{\mathrm{A}-\mathrm{C}}$ Means with different superscripts within column differ $(P<0.05)$.

${ }^{1}$ Treatment: Before calving cows were fed a concentrate proportion of $60 \%$. Postpartum the concentrate proportion increased from 30 to $50 \%$ within $3 \mathrm{wk}$ in all groups. CLA $(\mathrm{n}=16)$ and CLA + vitamin $\mathrm{E}(\mathrm{n}=12)$ received $8.4 \mathrm{~g}$ of trans-10, cis-12 CLA/d (BASF Lutrell, Lampertheim, Germany). Vitamin E $(\mathrm{n}=15)$ and CLA + vitamin E groups received 2,327 IU of vitamin E/d (BASF Lutavit E 50). The control group (n $=$ 16) as well as the vitamin E group received $88 \mathrm{~g} / \mathrm{d}$ of a rumen-protected fat supplement.

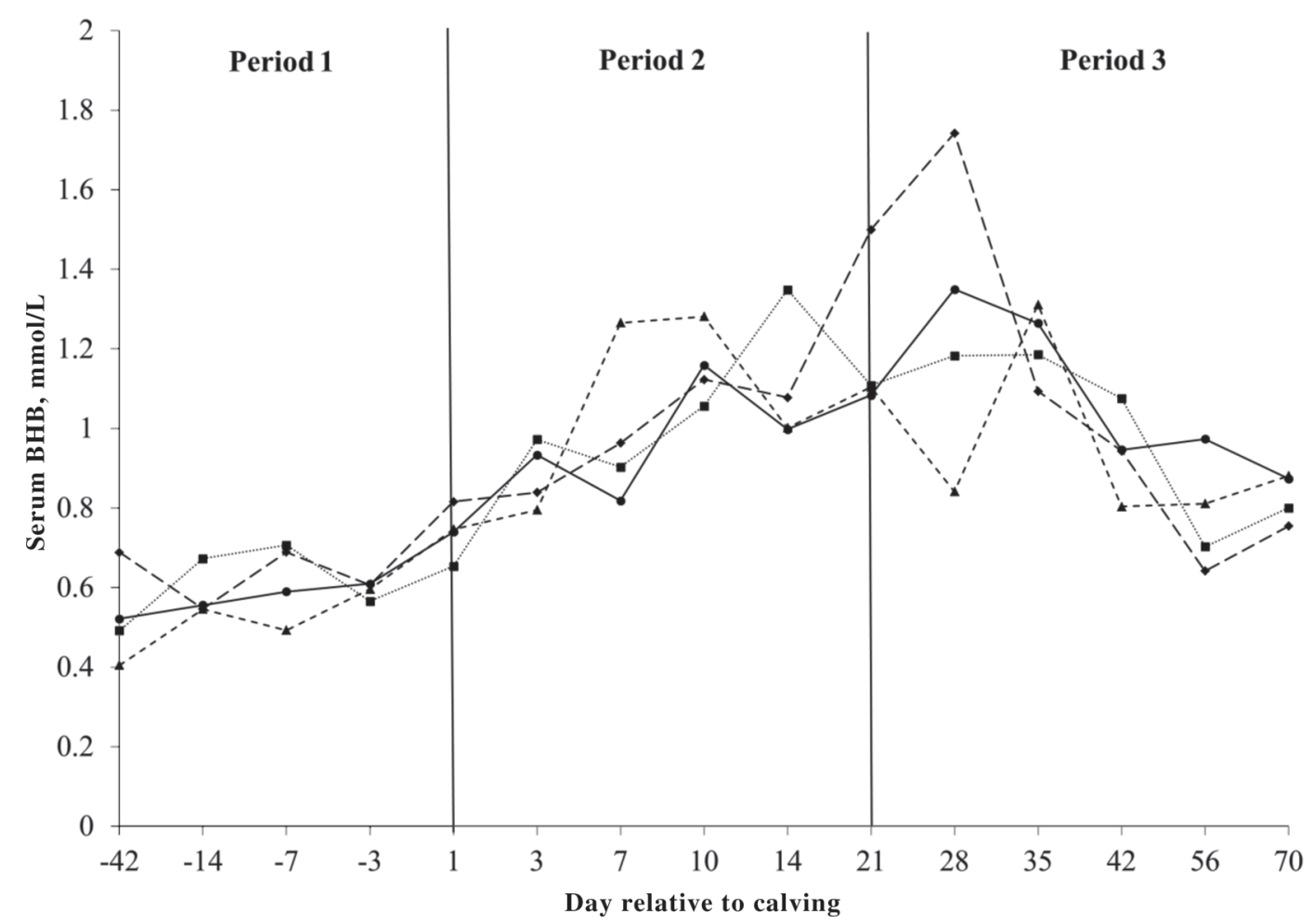

Figure 4. Serum BHB (LSM) during the experiment. Cows received a high-concentrate diet with a concentrate:roughage ratio of 60:40 antepartum. After parturition concentrate:roughage ratio increased stepwise from 30:70 to 50:50 within $21 \mathrm{~d}$ in all groups. Groups included a control group ( $\mathrm{n}=16 ; \boldsymbol{\bullet}$, solid line), a CLA group receiving $8.4 \mathrm{~g}$ of trans-10, cis-12 CLA $/ \mathrm{d}(\mathrm{n}=16$; $\mathbf{\square}$, dotted line), a vitamin $\mathrm{E}$ group ( $\mathrm{n}=$ 15) receiving $2,327 \mathrm{IU}$ of vitamin $\mathrm{E} / \mathrm{d}(\boldsymbol{\Lambda}$, short dashed line), and a group $(\mathrm{n}=12)$ receiving both treatments $(\bullet$, long dashed line) from $\mathrm{d}-42$ until 70 relative to calving. 
Table 5. Concentrations of BHB, fatty acids, and glucose in blood serum (LSM) of the experimental groups during periods 1 (d 42 antepartum until calving), 2 (d 1 until d 21 postpartum), and 3 (d 22 until d 70 postpartum)

\begin{tabular}{|c|c|c|c|c|c|c|c|c|c|}
\hline \multirow[b]{2}{*}{ Item } & \multicolumn{4}{|c|}{ Treatment $^{1}$} & \multirow[b]{2}{*}{ SEM } & \multicolumn{4}{|c|}{$P$-value } \\
\hline & $\begin{array}{c}\text { Control, } \\
\mathrm{n}=16\end{array}$ & $\begin{array}{c}\text { CLA, } \\
\mathrm{n}=16\end{array}$ & $\begin{array}{l}\text { Vitamin } \mathrm{E} \\
\mathrm{n}=15\end{array}$ & $\begin{array}{c}\text { CLA + } \\
\text { vitamin E, } \\
\mathrm{n}=12\end{array}$ & & CLA & Vitamin E & Period & $\begin{array}{l}\mathrm{CLA} \times \\
\text { vitamin } \mathrm{E} \\
\times \text { period }\end{array}$ \\
\hline \multicolumn{10}{|c|}{$\mathrm{BHB}, \mathrm{mmol} / \mathrm{L}$} \\
\hline Period 1 & $0.57^{\mathrm{b}}$ & $0.66^{\mathrm{b}}$ & $0.59^{\mathrm{b}}$ & 0.59 & 0.07 & 0.884 & 0.906 & $<0.001$ & 0.734 \\
\hline Period 2 & $0.98^{\mathrm{ab}}$ & $1.08^{\mathrm{a}}$ & $1.10^{\mathrm{a}}$ & 1.06 & 0.06 & & & & \\
\hline \multicolumn{10}{|c|}{ Fatty acids, mmol/L } \\
\hline Period 1 & $0.20^{\mathrm{b}}$ & $0.20^{\mathrm{b}}$ & $0.25^{\mathrm{b}}$ & $0.33^{\mathrm{b}}$ & 0.03 & 0.654 & 0.603 & $<0.001$ & 0.404 \\
\hline Period 2 & $0.64^{\mathrm{a}}$ & $0.63^{\mathrm{a}}$ & $0.67^{\mathrm{a}}$ & $0.60^{\mathrm{a}}$ & 0.03 & & & & \\
\hline Period 3 & $0.38^{\mathrm{b}}$ & $0.31^{\mathrm{b}}$ & $0.35^{\mathrm{b}}$ & $0.31^{\mathrm{b}}$ & 0.02 & & & & \\
\hline \multicolumn{10}{|c|}{ Glucose, mmol/L } \\
\hline Period 1 & $2.94^{\mathrm{a}}$ & 2.79 & $2.92^{\mathrm{a}}$ & $2.96^{\mathrm{a}}$ & 0.05 & 0.693 & 0.383 & $<0.001$ & \\
\hline Period 2 & $2.47^{\mathrm{b}}$ & 2.59 & $2.42^{\mathrm{c}}$ & $2.34^{\mathrm{b}}$ & 0.05 & & & & 0.218 \\
\hline Period 3 & $2.80^{\mathrm{ab}}$ & 3.00 & $2.77^{\mathrm{b}}$ & $2.81^{\mathrm{a}}$ & 0.05 & & & & \\
\hline
\end{tabular}

${ }^{\mathrm{a}-\mathrm{c}}$ Means with different superscripts within column differ $(P<0.05)$.

${ }^{1}$ Treatment: Before calving cows were fed a concentrate proportion of $60 \%$. Postpartum the concentrate proportion increased from 30 to $50 \%$ within 3 wk in all groups. CLA $(\mathrm{n}=16)$ and CLA + vitamin $\mathrm{E}(\mathrm{n}=12)$ received $8.4 \mathrm{~g}$ of trans-10,cis-12 CLA/d (BASF Lutrell, Lampertheim, Germany). Vitamin E $(\mathrm{n}=15)$ and CLA + vitamin E groups received 2,327 IU of vitamin E/d (BASF Lutavit E 50). The control group (n = 16) as well as the vitamin E group received $88 \mathrm{~g} / \mathrm{d}$ of a rumen-protected fat supplement.

however, this result might be generated by a different study design, in which cows received CLA not during the complete trial (wk 3 a.p. to 18 p.p) but only from wk 3 a.p. until wk 9 p.p. An increase of DMI was also found by de Veth et al. (2005) and Castañeda-Gutiérrez et al. (2007); however, in both studies, the treatment with CLA began when animals were already in lactation. Therefore, it is suggested that the effect of CLA on the DMI is dose- and time-dependent. As a consequence of the decreased DMI in animals that received CLA, net energy intake was 6 to $11 \%$ lower than in control animals in our study. As milk energy output between CLA-treated animals and the other groups did not differ, and CLA-treated animals did not show an enhanced fat depot mobilization, it is assumed that the efficiency was increased. This is reflected by lower, albeit not significant, RSEI in animals receiving CLA. Total liver lipid content did increase p.p. in our experiment; this is in accordance with the findings of Janovick et al. (2011) and Douglas et al. (2006), who observed that high-energy diets did not increase the total liver lipid content a.p. while enhancing it p.p. Milk yield was 2 to $8 \%$ higher in period 2 and $3 \%$ higher in period 3 in CLA-treated cows. This change in milk yield is confirmed by Von Soosten et al. (2011), who found slight effects of CLA on milk yield. A decrease in milk fat content of $13 \%$ for the CLA group and $5 \%$ for the CLA + Vit. E group compared with the control group was stated in period 2. The reduction of milk fat content in the Vit. E group was $9 \%$. In period 3 the reduction was 25, 18, and 5\% for the CLA, CLA + Vit. E, and Vit. E groups, respectively. The level of milk fat content

Table 6. Total lipid content in liver as $\mathrm{mg} / \mathrm{g}$ of wet tissue weight of the experimental groups on d 42 antepartum (a.p.), d 7,28 , and 70 postpartum (p.p.) (LSM)

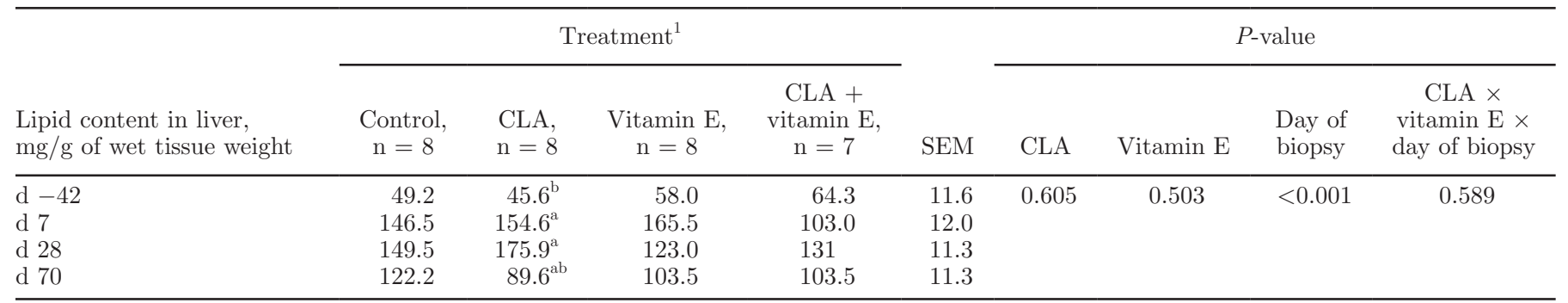

\footnotetext{
${ }_{\mathrm{a}, \mathrm{b}}$ Means with different superscripts within column differ $(P<0.05)$.

${ }^{1}$ Treatment: Before calving cows were fed a concentrate proportion of $60 \%$. Postpartum the concentrate proportion increased from 30 to $50 \%$ within $3 \mathrm{wk}$ in all groups. CLA $(\mathrm{n}=16)$ and CLA + vitamin $\mathrm{E}(\mathrm{n}=12)$ received $8.4 \mathrm{~g}$ of trans-10, cis-12 CLA/d (BASF Lutrell, Lampertheim, Germany). Vitamin E $(\mathrm{n}=15)$ and CLA + vitamin E groups received 2,327 IU of vitamin E/d (BASF Lutavit E 50). The control group (n $=$ 16) as well as the vitamin E group received $88 \mathrm{~g} / \mathrm{d}$ of a rumen-protected fat supplement.
} 
reduction in the CLA group is in accordance with other studies applying similar doses of trans-10,cis-12 CLA. Perfield et al. (2002) showed that the application of 3 $\mathrm{g} / \mathrm{d}$ of trans-10,cis-12 CLA led to a milk fat content decrease of $23 \%$ in late lactation, whereas CastañedaGutiérrez et al. (2005) demonstrated a reduction of $10 \%$ at a dose of $9 \mathrm{~g} / \mathrm{d}$ of trans-10,cis-12 CLA during the first 9 wk of lactation.

We found no evidence for a reduction of milk fat content in dairy cows by vitamin E. Pottier et al. (2006) and Liu et al. (2008) showed an increase of milk fat content in cows treated with vitamin $\mathrm{E}$; however, Pottier et al. (2006) used a daily dose of 12,000 IU, whereas Liu et al. (2008) administered doses of 5,000 or 10,000 IU compared with 2,327 IU used in our study. Furthermore, cows were on a high-fat diet in the experiment by Pottier et al. (2006); therefore, it is concluded that higher doses of vitamin $\mathrm{E}$ than our $2,327 \mathrm{IU} / \mathrm{d}$ are necessary to show a reducing effect on milk fat content. Our results suggest an interaction between vitamin $\mathrm{E}$ and CLA, as the reduction of milk fat content was lower in the group receiving both treatments in comparison to the CLA group. Dawson and Herbein (1996) observed that the uptake of CLA by bovine mammary cells is proportional to the level of CLA in the medium. Consequently, it is assumed that the CLA levels in the blood are reduced in the CLA + Vit. E group compared with the group receiving only CLA. According to Pottier et al. (2006), vitamin E in high doses is able to prevent the trans-11 to trans-10 shift in the rumen; however, vitamin $\mathrm{E}$ only partly reverses the shift once it had occurred. Therefore, the trans10,cis-12 CLA in the CLA + Vit. E group might partly be transformed to trans-11 isomers, resulting in lower blood levels of trans-10, cis-12 CLA and, consequently, less reduction of milk fat content. As shown by Weiss et al. (1995), vitamin $\mathrm{E}$ is not affected in the rumen; therefore, vitamin E might influence CLA at different sites. Kay et al. (2005) reported a change of plasma levels of different trans fatty acids after application of $\alpha$-tocopherol, suggesting that vitamin E might influence biohydrogenation in the rumen. Analysis of CLA levels in duodenal content and in blood is necessary to further clarify the site of interaction between vitamin $\mathrm{E}$ and CLA. As a consequence of the reduced milk fat content and a decreased milk yield in period 2, as well as an only slightly increased milk yield in period 3 in the CLA and CLA + Vit. E groups, the total milk fat synthesis was reduced. In our study, a milk yield increase in lactation wk 2 was observed, milk yield then decreased. Different patterns of milk fat yield reduction by CLA are also described in literature. In the study of Perfield et al. (2002), a decrease of milk fat yield occurred from wk 1 on. Metzger-Petersen (2012) reported no decrease of milk fat yield, whereas Moore et al. (2004) observed milk fat yield decrease beginning in wk 2 after parturition, similar to our results.

Von Soosten et al. (2011) found a decelerated decrease in milk fat yield beginning in wk 4 p.p. A reason for the delayed onset of milk fat yield reduction might be that the effect of CLA is masked by enhanced lipomobilization during early lactation. Fatty acids in milk can be derived either from fatty acids circulating in blood or be de novo synthesized in the mammary cells. Conjugated linoleic acid is known to reduce the de novo synthesis of fatty acids from acetate. However, in a state of energy deficiency, fatty acids from body fat mobilization increase proportionally, thereby reducing the proportion of de novo synthesized fatty acids (Bauman and Griinari, 2003). As dairy cows are in a negative energy balance after calving in early lactation, the contribution of fatty acids mobilized from adipose tissues to milk fat synthesis is relatively high.

Nousiainen et al. (2004) conducted a meta-analysis and proved that milk urea depends highly on dietary CP. As dietary CP did not differ between groups in our study, it is suggested that the reduced milk urea content during period 3 is a consequence of the lower DMI, and consequently CP intake, in cows treated with CLA. Milk protein content and yield were not affected by treatment; this is confirmed by other experiments not showing an influence of CLA on milk protein (Bernal-Santos et al., 2003; Moore et al., 2004; Perfield et al., 2004; Metzger-Petersen, 2012). The reduced milk fat:protein ratios and milk energy concentrations in CLA-receiving animals could be explained as a direct consequence of a milk fat reduction while the milk protein stayed constant. The reduced milk energy output in both groups receiving CLA is accompanied by the decreased DM and energy intake. Thus, CLA did not enhance the energy balance in our trial. The residual energy intake of the CLA group was negative in both periods, indicating this group had a more efficient use of energy compared with the other groups.

Changes in adipose tissue of dairy cows during transition period and the effects CLA and vitamin E have on them have not been extensively researched. Animals in our study experienced a daily loss of fat depot mass of 0.10 to $0.66 \mathrm{~kg}$ between 8 and 28 DIM, which is comparable to other studies (Andrew et al., 1994; Komaragiri and Erdman, 1997). In our trial, no differences in change of the subcutaneous fat depots between groups were found; as the correlation between back fat thickness and BCS is high (0.96-0.98; Hussein et al., 2013) and BCS between groups did not differ, this finding is in concordance with our other results. In the mouse (DeLany et al., 1999; Tsuboyama-Kasaoka et al., 2000; Clément et al., 2002; Warren et al., 2003; Poirier et 
al., 2005) and humans (Risérus et al., 2001; Belury et al., 2003), trans-10,cis-12 CLA has been shown to be responsible for a reduction of abdominal adipose tissue. DeLany et al. (1999) reported that CLA has a major influence on the retroperitoneal adipose tissue depot in mice. Studies by von Soosten et al. (2011) suggested a decelerated mobilization of the retroperitoneal fat depot for dairy cows. However, the outcomes of our trial indicate that CLA did not influence the change of the retroperitoneal fat depot during the viewed periods. The contradictory results of von Soosten et al. (2011) might be due to the fact that they used only primiparous cows in their study. Berry et al. (2007) and Roche (2007) reported that primiparous cows are more sensitive to lipomobilization after parturition than pluriparous cows, and their ability to compensate this loss is impaired. Furthermore, administration of CLA began after calving compared with 6 wk before parturition in our study.

\section{CONCLUSIONS}

It was possible to induce a susceptibility to lipomobilization and subclinical ketosis in cows after parturition using a high concentrate proportion before calving and a decelerated increase in concentrate after calving. Treatment with vitamin $\mathrm{E}$ counteracts the milk fat-decreasing effect of CLA and thereby reduces the effect that CLA has on milk energy output. In addition, results suggest that the effects CLA had on milk content, thereby reducing the milk energy output, were compensated by a slightly increased milk yield and a decreased DMI. Therefore, the net energy balance was not affected by either treatment. Consequently, the lipomobilization was not reduced by either treatment. Thus, it was not possible to reduce the prevalence of subclinical ketosis by treatment with CLA. Further studies are needed to clarify the mechanisms behind the interaction effects between CLA and vitamin E on milk fat.

\section{ACKNOWLEDGMENTS}

The authors thank co-workers at the Institute of Animal Nutrition and the Experimental Station of the Friedrich-Loeffler-Institute (FLI) in Brunswick Germany, for performing the experiment and analyses. The study was supported by BASF, Ludwigshafen, Germany.

\section{REFERENCES}

Akter, S. H., S. Haussler, S. Danicke, U. Muller, D. von Soosten, J. Rehage, and H. Sauerwein. 2011. Physiological and conjugated lin- oleic acid-induced changes of adipocyte size in different fat depots of dairy cows during early lactation. J. Dairy Sci. 94:2871-2882.

Andrew, S. M., D. Waldo, and R. Erdman. 1994. Direct analysis of body composition of dairy cows at three physiological stages. J. Dairy Sci. 77:3022-3033. https://doi.org/10.3168/jds.S00220302(94)77244-1.

Bauman, D. E., and J. M. Griinari. 2003. Nutritional regulation of milk fat synthesis. Annu. Rev. Nutr. 23:203-227. https://doi. org/10.1146/annurev.nutr.23.011702.073408.

Bauman, D. E., J. W. Perfield, K. J. Harvatine, and L. H. Baumgard. 2008. Regulation of fat synthesis by conjugated linoleic acid: Lactation and the ruminant model. J. Nutr. 138:403-409.

Baumgard, L. H., B. A. Corl, D. A. Dwyer, A. Saebo, and D. E. Bauman. 2000. Identification of the conjugated linoleic acid isomer that inhibits milk fat synthesis. Am. J. Physiol. 278:R179-R184.

Belury, M. A., A. Mahon, and S. Banni. 2003. The conjugated linoleic acid (CLA) isomer, t10c12-CLA, is inversely associated with changes in body weight and serum leptin in subjects with type 2 diabetes mellitus. J. Nutr. 133:257S-260S.

Bernabucci, U., B. Ronchi, N. Lacetera, and A. Nardone. 2005. Influence of body condition score on relationships between metabolic status and oxidative stress in periparturient dairy cows. J. Dairy Sci. 88:2017-2026.

Bernal-Santos, G., J. W. Perfield, D. M. Barbano, D. E. Bauman, and T. R. Overton. 2003. Production responses of dairy cows to dietary supplementation with conjugated linoleic acid (CLA) during the transition period and early lactation. J. Dairy Sci. 86:3218-3228. https://doi.org/10.3168/jds.S0022-0302(03)73925-3.

Berry, D. P., F. Buckley, and P. Dillon. 2007. Body condition score and live-weight effects on milk production in Irish Holstein-Friesian dairy cows. Animal 1:1351-1359. https://doi.org/10.1017/ S1751731107000419.

Bobe, G., J. W. Young, and D. C. Beitz. 2004. Invited review: Pathology, etiology, prevention, and treatment of fatty liver in dairy cows. J. Dairy Sci. 87:3105-3124.

Castañeda-Gutiérrez, E., B. C. Benefield, M. J. de Veth, N. R. Santos, R. O. Gilbert, W. R. Butler, and D. E. Bauman. 2007. Evaluation of the mechanism of action of conjugated linoleic acid isomers on reproduction in dairy cows. J. Dairy Sci. 90:4253-4264. https:// doi.org/10.3168/jds.2007-0117.

Castañeda-Gutiérrez, E., T. R. Overton, W. R. Butler, and D. E. Bauman. 2005. Dietary supplements of two doses of calcium salts of conjugated linoleic acid during the transition period and early lactation. J. Dairy Sci. 88:1078-1089. https://doi.org/10.3168/jds. S0022-0302(05)72775-2.

Chao, P. M., W. H. Chen, C. H. Liao, and H. M. Shaw. 2010. Conjugated linoleic acid causes a marked increase in liver alpha-tocopherol and liver alpha-tocopherol transfer protein in C57BL/6 J mice. Int. J. Vitam. Nutr. Res. 80:65-73.

Clément, L., H. Poirier, I. Niot, V. Bocher, M. Guerre-Millo, S. Krief, B. Staels, and P. Besnard. 2002. Dietary trans-10, cis-12 conjugated linoleic acid induces hyperinsulinemia and fatty liver in the mouse. J. Lipid Res. 43:1400-1409. https://doi.org/10.1194/jlr. M20008-JLR200.

Dawson, S. E., and J. H. Herbein. 1996. Influence of exogenous unsaturated fatty acids on de novo synthesis of saturated fatty acids in mouse and bovine mammary cell cultures. Va. J. Sci. 47:138. (Abstr.).

de Veth, M. J., S. K. Gulati, N. D. Luchini, and D. E. Bauman. 2005. Comparison of calcium salts and formaldehyde-protected conjugated linoleic Acid in inducing milk fat depression. J. Dairy Sci 88:1685-1693. https://doi.org/10.3168/jds.S0022-0302(05)72840$\mathrm{X}$.

DeLany, J. P., F. Blohm, A. A. Truett, J. A. Scimeca, and D. B. West. 1999. Conjugated linoleic acid rapidly reduces body fat content in mice without affecting energy intake. Am. J. Physiol. 276:R1172R1179.

Douglas, G. N., T. R. Overton, H. G. Bateman, H. M. Dann, and J. K. Drackley. 2006. Prepartal plane of nutrition, regardless of dietary energy source, affects periparturient metabolism and dry matter 
intake in Holstein cows. J. Dairy Sci. 89:2141-2157. https://doi. org/10.3168/jds.S0022-0302(06)72285-8.

Drackley, J. K. 1999. Biology of dairy cows during the transition period: The final frontier? J. Dairy Sci. 82:2259-2273. https://doi. org/10.3168/jds.S0022-0302(99)75474-3.

Drackley, J. K., R. L. Wallace, D. Graugnard, J. Vasquez, B. F. Richards, and J. J. Loor. 2014. Visceral adipose tissue mass in nonlactating dairy cows fed diets differing in energy density. J. Dairy Sci. 97:3420-3430.

Drong, C., U. Meyer, D. von Soosten, J. Frahm, J. Rehage, G. Breves, and S. Danicke. 2016. Effect of monensin and essential oils on performance and energy metabolism of transition dairy cows. J. Anim. Physiol. Anim. Nutr. (Berl.) https://doi.org/10.1111/ jpn. 12401.

Edmonson, A. J., I. J. Lean, L. D. Weaver, T. Farver, and G. Webster. 1989. A body condition scoring chart for Holstein dairy cows. J. Dairy Sci. 72:68-78. https://doi.org/10.3168/jds.S00220302(89)79081-0.

Gaines, W. L. 1928. An efficiency formula for dairy cows. Science 67:353-354. https://doi.org/10.1126/science.67.1735.353.

GfE. 2001. Empfehlung zur Energie- und Nährstoffversorgung von Milchkühen und Aufzuchtrindern. DLG-Verlag, Frankfurt am Main, Germany.

GfE. 2008. Communications of the Committee for Requirement Standards of the Society of Nutrition Physiology: New equations for predicting metabolisable energy of grass and maize products for ruminants. Proc. Soc. Nutr. Physiol. 17:191-198.

GfE. 2009. New Equations for Predicting Metabolisable Energy of Compound Feeds for Cattle. Proc. Soc. Nutr. Physiol. 18:143-146.

Gillund, P., O. Reksen, Y. Gröhn, and K. Karlberg. 2001. Body condition related to ketosis and reproductive performance in Norwegian dairy cows. J. Dairy Sci. 84:1390-1396. https://doi.org/10.3168/ jds.S0022-0302(01)70170-1.

Grummer, R. R. 1993. Etiology of lipid-related metabolic disorders in periparturient dairy cows. J. Dairy Sci. 76:3882-3896.

Grummer, R. R., P. C. Hoffman, M. L. Luck, and S. J. Bertics. 1995 Effect of prepartum and postpartum dietary energy on growth and lactation of primiparous cows. J. Dairy Sci. 78:172-180.

Heitmann, R. N., D. J. Dawes, and S. C. Sensenig. 1987. Hepatic ketogenesis and peripheral ketone-body utilization in the ruminant. J. Nutr. 117:1174-1180.

Holtenius, P., and K. Holtenius. 1996. New aspects of ketone bodies in energy metabolism of dairy cows: A review. J. Vet. Med. A Physiol. Pathol. Clin. Med. 43:579-587.

Hurley, A. M., N. Lopez-Villalobos, S. McParland, E. Kennedy, E. Lewis, M. O'Donovan, J. L. Burke, and D. P. Berry. 2016. Interrelationships among alternative definitions of feed efficiency in grazing lactating dairy cows. J. Dairy Sci. 99:468-479. https://doi. org/10.3168/jds.2015-9928.

Hussein, H. A., A. Westphal, and R. Staufenbiel. 2013. Relationship between body condition score and ultrasound measurement of backfat thickness in multiparous Holstein dairy cows at different production phases. Aust. Vet. J. 91:185-189. https://doi. org/10.1111/avj.12033.

Janovick, N. A., Y. R. Boisclair, and J. K. Drackley. 2011. Prepartum dietary energy intake affects metabolism and health during the periparturient period in primiparous and multiparous Holstein cows. J. Dairy Sci. 94:1385-1400. https://doi.org/10.3168/jds.2010-3303.

JP Committee, Pharmaceutical Affairs and Food Sanitation Council, Japanese Minister of Health, Labour and Welfare. 2011. The Japanese Pharmacopoeia. 16th ed. The Society of Japanese Pharmacopoeia, Tokyo, Japan.

Kay, J. K., J. R. Roche, E. S. Kolver, N. A. Thomson, and L. H. Baumgard. 2005. A comparison between feeding systems (pasture and TMR) and the effect of vitamin E supplementation on plasma and milk fatty acid profiles in dairy cows. J. Dairy Res. 72:322332. https://doi.org/10.1017/S0022029905000944.

Komaragiri, M. V., and R. A. Erdman. 1997. Factors affecting body tissue mobilization in early lactation dairy cows. 1. Effect of dietary protein on mobilization of body fat and protein. J. Dairy Sci. 80:929-937. https://doi.org/10.3168/jds.S0022-0302(97)76016-8.
Littell, R. C., P. R. Henry, and C. B. Ammerman. 1998. Statistical analysis of repeated measures data using SAS procedures. J. Anim. Sci. 76:1216-1231.

Liu, Z. L., D. P. Yang, P. Chen, W. X. Dong, and D. M. Wang. 2008. Supplementation with selenium and vitamin E improves milk fat depression and fatty acid composition in dairy cows fed fat diet. Asian-Australas. J. Anim. Sci. 21:838-844. https://doi. org/10.5713/ajas.2008.70618.

Metzger-Petersen, K. 2012. Supplementation of a rumen-protected conjugated linoleic acid mixture (cis-9,trans-11; trans-10,cis-12) to early lactation dairy cows-effects on feed intake and performance. Thesis. Faculty of Agriculture, Universitäts-und Landesbibliothek Bonn. Bonn, Germany.

Moore, C. E., H. C. Hafliger, O. B. Mendivil, S. R. Sanders, D. E. Bauman, and L. H. Baumgard. 2004. Increasing amounts of conjugated linoleic acid (CLA) progressively reduces milk fat synthesis immediately postpartum. J. Dairy Sci. 87:1886-1895. https://doi. org/10.3168/jds.S0022-0302(04)73347-0.

Nakamura, Y. K., and S. T. Omaye. 2010. Lipophilic compound-mediated gene expression and implication for intervention in reactive oxygen species (ROS)-related diseases: Mini-review. Nutrients 2:725-736.

Nielen, M., M. G. A. Aarts, A. G. M. Jonkers, T. Wensing, and Y. H. Schukken. 1994. Evaluation of 2 cowside tests for the detection of subclinical ketosis in dairy cows. Can. Vet. J. 35:229-232.

Nousiainen, J., K. Shingfield, and P. Huhtanen. 2004. Evaluation of milk urea nitrogen as a diagnostic of protein feeding. J. Dairy Sci. 87:386-398. https://doi.org/10.3168/jds.S0022-0302(04)73178-1.

Odens, L. J., R. Burgos, M. Innocenti, M. J. VanBaale, and L. H. Baumgard. 2007. Effects of varying doses of supplemental conjugated linoleic acid on production and energetic variables during the transition period. J. Dairy Sci. 90:293-305. https://doi. org/10.3168/jds.S0022-0302(07)72630-9.

Pappritz, J., U. Meyer, R. Kramer, E. M. Weber, G. Jahreis, J. Rehage, G. Flachowsky, and S. Danicke. 2011. Effects of long-term supplementation of dairy cow diets with rumen-protected conjugated linoleic acids (CLA) on performance, metabolic parameters and fatty acid profile in milk fat. Arch. Anim. Nutr. 65:89-107. https://doi.org/10.1080/1745039X.2011.552275.

Perfield, J. W., G. Bernal-Santos, T. R. Overton, and D. E. Bauman. 2002. Effects of dietary supplementation of rumen-protected conjugated linoleic acid in dairy cows during established lactation. J. Dairy Sci. 85:2609-2617. https://doi.org/10.3168/jds.S00220302(02) 74346-4.

Perfield, J. W., A. L. Lock, A. M. Pfeiffer, and D. E. Bauman. 2004. Effects of amide-protected and lipid-encapsulated conjugated linoleic acid (CLA) supplements on milk fat synthesis. J. Dairy Sci. 87:3010-3016. https://doi.org/10.3168/jds.S0022-0302(04)734323 .

Poirier, H., I. Niot, L. Clement, M. Guerre-Millo, and P. Besnard. 2005. Development of conjugated linoleic acid (CLA)-mediated lipoatrophic syndrome in the mouse. Biochimie 87:73-79. https:// doi.org/10.1016/j.biochi.2004.11.006

Pottier, J., M. Focant, C. Debier, G. De Buysser, C. Goffe, E. Mignolet, E. Froidmont, and Y. Larondelle. 2006. Effect of dietary vitamin $\mathrm{E}$ on rumen biohydrogenation pathways and milk fat depression in dairy cows fed high-fat diets. J. Dairy Sci. 89:685-692. https://doi.org/10.3168/jds.S0022-0302(06)72131-2.

Raschka, C., L. Ruda, P. Wenning, C.-I. von Stemm, C. Pfarrer, K. Huber, U. Meyer, S. Dänicke, and J. Rehage. 2016. In vivo determination of subcutaneous and abdominal adipose tissue depots in German Holstein dairy cattle. J. Anim. Sci. https://doi. org/10.2527/jas.2015-0103.

Rimbach, G., A. M. Minihane, J. Majewicz, A. Fischer, J. Pallauf, F. Virgli, and P. D. Weinberg. 2002. Regulation of cell signalling by vitamin E. Proc. Nutr. Soc. 61:415-425.

Risérus, U., L. Berglund, and B. Vessby. 2001. Conjugated linoleic acid (CLA) reduced abdominal adipose tissue in obese middleaged men with signs of the metabolic syndrome: A randomised controlled trial. Int. J. Obes. Relat. Metab. Disord. 25:1129-1135. 
Roche, J. R. 2007. Milk production responses to pre- and postcalving dry matter intake in grazing dairy cows. Livest. Sci. 110:12-24. https://doi.org/10.1016/j.livsci.2006.08.016.

Schlegel, G., R. Ringseis, M. Shibani, E. Most, M. Schuster, F. J. Schwarz, and K. Eder. 2012. Influence of a rumen-protected conjugated linoleic acid mixture on carcass traits and meat quality in young Simmental heifers. J. Anim. Sci. 90:1532-1540.

Schulz, K., J. Frahm, U. Meyer, S. Kersten, D. Reiche, J. Rehage, and S. Danicke. 2014. Effects of prepartal body condition score and peripartal energy supply of dairy cows on postpartal lipolysis, energy balance and ketogenesis: An animal model to investigate subclinical ketosis. J. Dairy Res. 81:257-266. https://doi.org/10.1017/ S0022029914000107.

Sjaunja, L., L. Baevre, L. Junkkarinen, J. Pedersen, and J. Setälä. 1990. A Nordic proposal for an energy corrected milk (ECM) formula. Proc. 27th Session of International Committee for Recording Productivity of Milk Animals (ICRPMA). Eur. Assoc. Anim. Prod. Publ. 50:156-157.

Starke, A., A. Haudum, R. Busche, M. Beyerbach, S. Danicke, and J. Rehage. 2010. Technical note: Analysis of total lipid and triacylglycerol content in small liver biopsy samples in cattle. J. Anim. Sci. 88:2741-2750. https://doi.org/10.2527/jas.2009-2599.

Tsuboyama-Kasaoka, N., M. Takahashi, K. Tanemura, H.-J. Kim, T. Tange, H. Okuyama, M. Kasai, S. Ikemoto, and O. Ezaki. 2000.
Conjugated linoleic acid supplementation reduces adipose tissue by apoptosis and develops lipodystrophy in mice. Diabetes 49:1534-1542. https://doi.org/10.2337/diabetes.49.9.1534.

VDLUFA. 1993. Handbuch der Landwirtschaftlichen Versuchs- und Untersuchungsmethodik (VDLUFA-Methodenbuch). Vol. III. VDLUFA-Verlag, Darmstadt, Germany.

von Soosten, D., U. Meyer, E. Weber, J. Rehage, G. Flachowsky, and S. Dänicke. 2011. Effect of trans-10, cis-12 conjugated linoleic acid on performance, adipose depot weights, and liver weight in early-lactation dairy cows. J. Dairy Sci. 94:2859-2870. https://doi. org/10.3168/jds.2010-3851.

Warren, J. M., V. Simon, G. Bartolini, K. Erickson, B. Mackey, and D. Kelley. 2003. Trans-10,cis-12 CLA increases liver and decreases adipose tissue lipids in mice: Possible roles of specific lipid metabolism genes. Lipids 38:497-504. https://doi.org/10.1007/s11745003-1090-0.

Weiss, W. P., K. L. Smith, J. S. Hogan, and T. E. Steiner. 1995. Effect of forage to concentrate ratio on disappearance of vitamin-a and vitamin-e during in vitro ruminal fermentation. J. Dairy Sci. 78:1837-1842. https://doi.org/10.3168/jds.S0022-0302(95)76808- 